\title{
Discourse and Identity in the Digital World: Mansoura University Website as a Model
}

\author{
Dr. Rehab Farouk Gad \\ Associate Professor of Linguistics, Mansoura University \\ Faculty of Arts, Department of English
}

\begin{abstract}
:
Digital Discourse is concerned with the manipulation of multimodal and multi-semiotic resources which are investigated to characterize identities and ideologies in a digital world that is said to be a part of a whole society, as claimed by Gee (2005). A digital text is a type of human communication that can be described as multimodal by incorporating writing, images, sounds and other semiotic systems. In the last three decades, people have become more attracted to say so many things about themselves and their activities through digital media. However, attempts to give a comprehensive image of a college or university are limited. The present study aims to signify how a digital text can reflect ideologies and realities about the social and academic life of Mansoura University, located in Mansoura city, the capital of Dakahlia Governorate on the east bank of the Nile in Egypt. The data employed as the basis of the analysis in this study is extracted from large database of announcements, texts and images displayed on Mansoura University website in 2020 (following the widespread transmission of Covid-19). The study proposes a multidisciplinary analysis of Mansoura University website, following Darvin (2016) and Petroni (2019). Mansoura University website is said to be an attempt by a collective institution to establish an image of itself on the internet. The digitized discourse is designed to provide a collective image that replicates the identity of Mansoura University and highlights its position (inter)nationally. Dealing with the information displayed on the target website as a type of commodity that possesses multiple traits and, at the same time, reflects issues of identity and reputation building, the study concludes that the analysis of the digital discourse has assigned Mansoura University a type of identity that can be described as a Commodified Identity.
\end{abstract}

Keywords:

digital discourse, multimodality, social capital, self-promotion, commodity, informalization, marketization, translocality. 
(ISSN : 2536 - 9555)

\author{
الخطاب والههوية في العالم الرقمي: موقع جامعة المنصورة نموذجًا

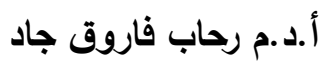 \\ أستاذ اللغويات والترجمة المساعد \\ كلية الآداب- جامعة المنصورة- قسم اللغة الإنجليزية
}

ملخص البحث باللغة العربية:

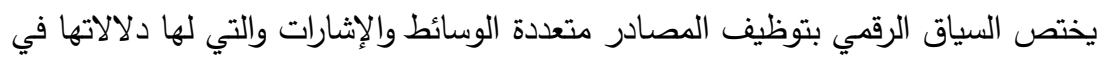

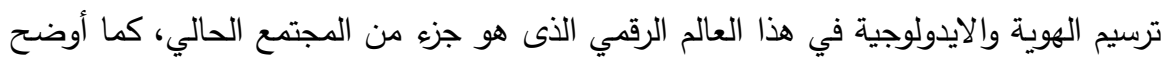

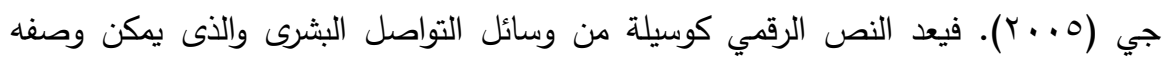

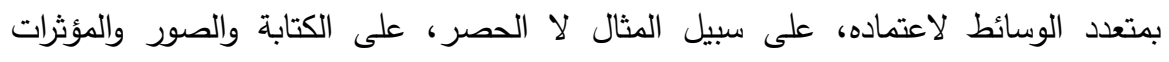

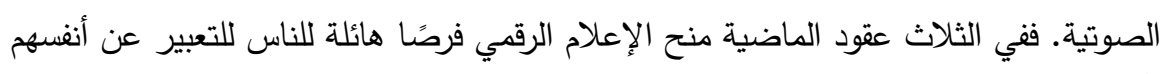

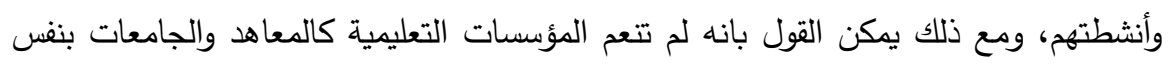

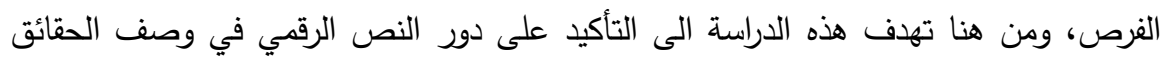

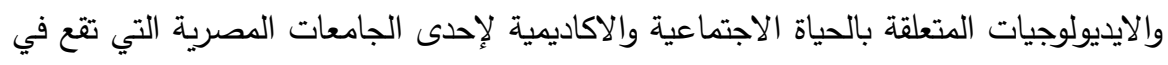

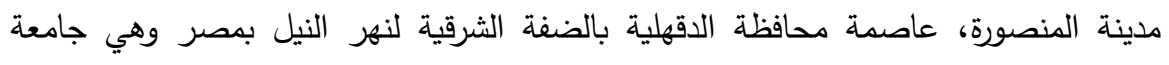

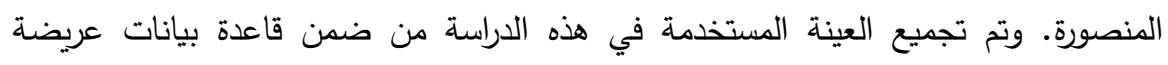

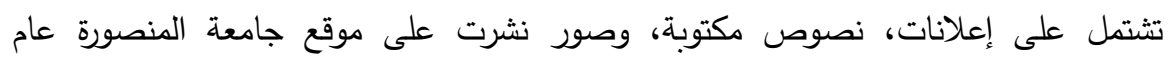

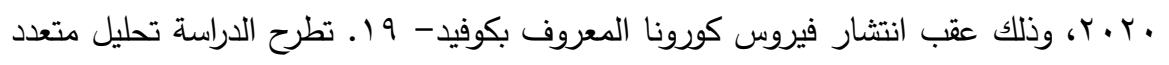

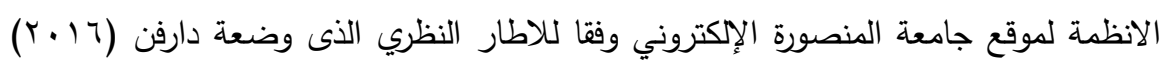

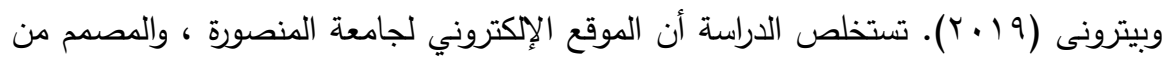

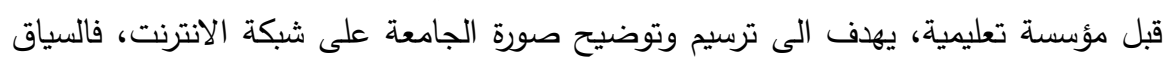

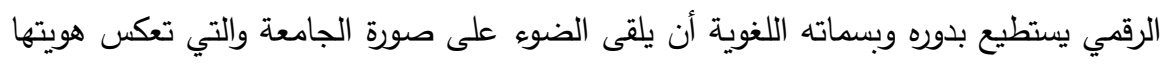

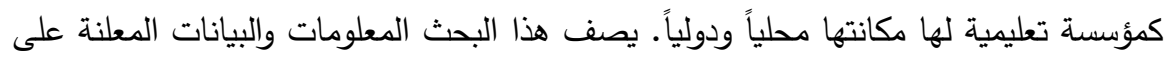

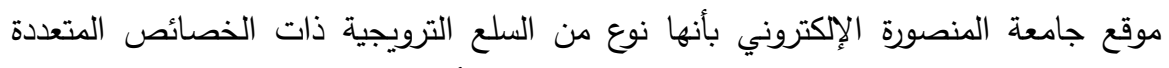

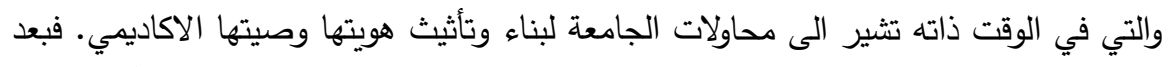

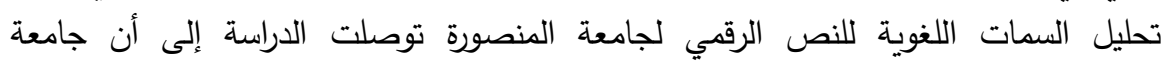

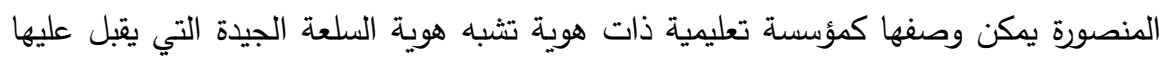

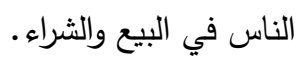

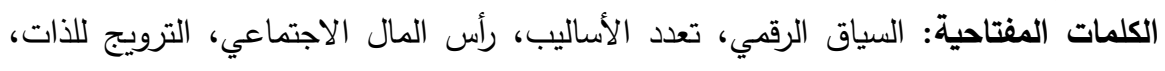

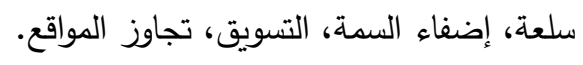


Discourse and Identity in the Digital World: Mansoura University Website as a Model

Dr. Rehab Farouk Gad

مجلة وادي النيل للاراسات والبحوث الإنسانية والاجتماعية والتربوية (مجلة علمية محكمة)

\section{Introduction}

Webpage design has gone through the following three subsequent phases as suggested by Kelly (2013): Antiquity (early 1990s, text only as in excerpt a), The Middle Ages (mid 1990s, graphical elements appeared on column-based formats as in excerpt $b$ ), The Renaissance (use of features like flash as in excerpt c).

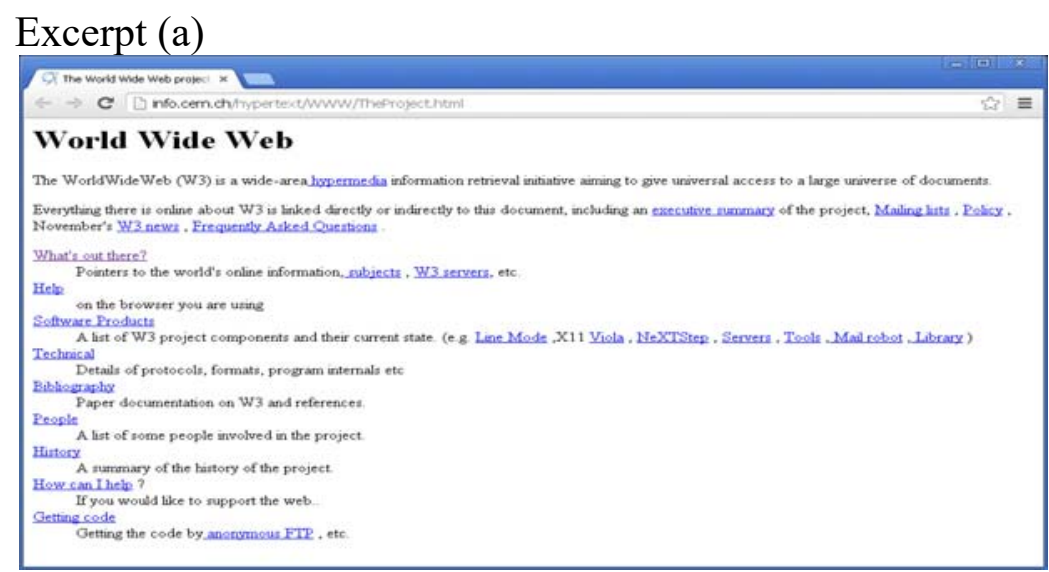

Excerpt (b)

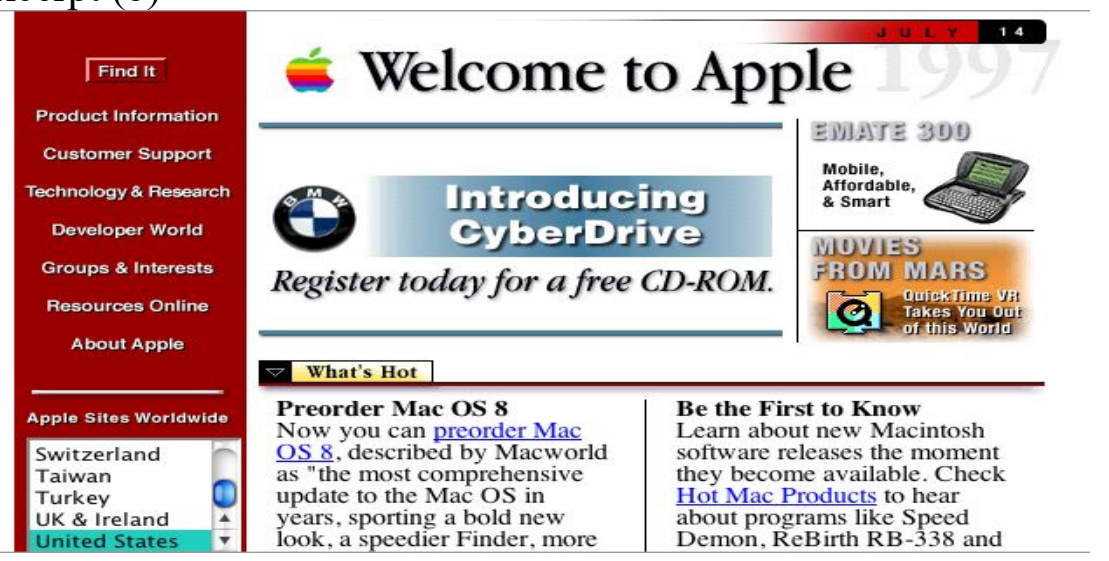


مجلة وادي النيل للاراسات والبحوث الإنسانية والاجتماعية والتربوية (مجلة علمية محكمة)

(ISSN : 2536 - 9555)

\section{Excerpt (c)}

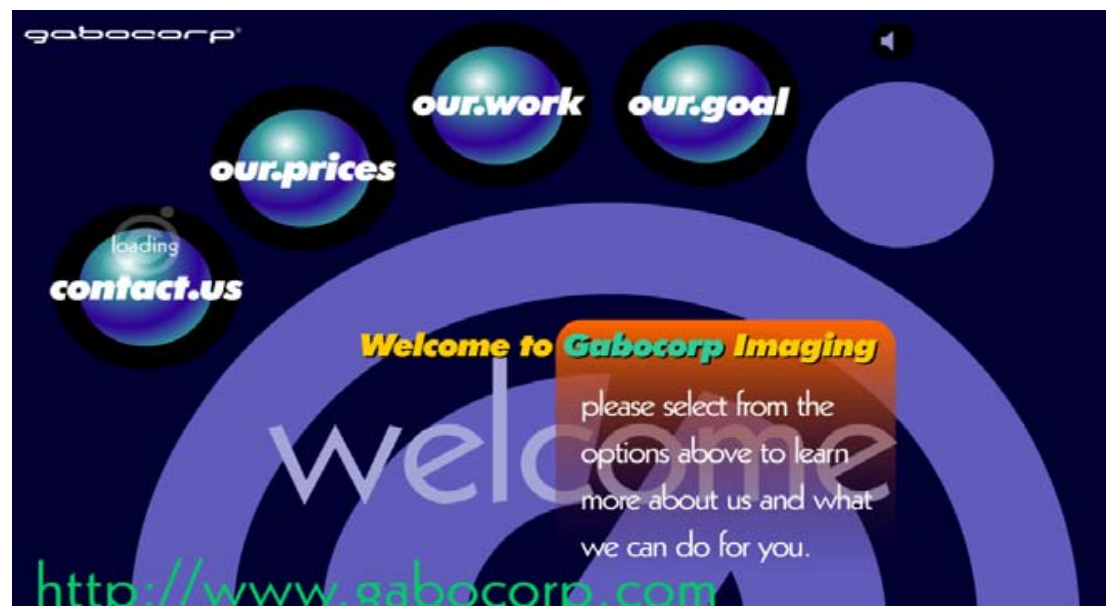

Before embarking on how Mansoura University website is designed in such a way that reflects issues of identity by languageoriented means, definition of digital discourse and its characteristics is given. According to Fairclough (1992, p. 29), discourse is mainly a social practice and is not concerned with language in use. Therefore, Discourse Analysis investigates how people build and view their social life by employing semiotic systems as argued by Jones, Chik and Hafner (2015). Users of web 2.0, with personal or corporate profiles, are in a continuous struggle to keep up with its nature and use it as a medium of meaning making and self-presentation (Goffman 1959, Jenkins 2006 and Chouliaraki\& Morsing 2009). This challenge has paved the way for the appearance of a type of discourse that is purely digitized in nature. Digital discourse is a new paradigm of communication that analyzes what people say via social media and explains how digital connections and interactions underpin what they do. According to Müller (2017), digital linguistics is mainly concerned with measuring, categorizing and contextualizing certain categories in language corpora and certain data which identify both language use and language speakers. 
Discourse and Identity in the Digital World: Mansoura University Website as a Model

Dr. Rehab Farouk Gad

\section{مجلة وادي النيل للاراسات والبحوث الإنسانية والاجتماعية والتربوية (مجلة علمية محكمة)}

Digital discourse analysis has the following features: (1) digital data is the center of analysis; (2) a set of data is usually compared with another set of data; (3) data is measured, classified and categorized; (4) tokenization or assigning letters to word category takes place; (5) assigning words to word class, or tagging of parts of speech is part of the analysis.

Discussions of the field of digital discourse analysis have gone through three waves: the first wave suggested the need for descriptive linguistic approaches; the second wave has produced Computer-Mediated Discourse Analysis (CMDS), developed by Herring (1996) in order to analyze digital texts. According to BouFranch and Blitvich $(2019$, p. 4), under the umbrella of the second wave, the following digital social practices are investigated:
a. Social diversity
b. Linguistic variability
c. Community formation and maintenance
d. Issues of identity
e. Community formation and maintenance

The third wave tackled issues of translocality, defined by BouFranch and Blitvich (2019, p. 4) as "the complex ways in which diverse local practices come together in global spaces". The social process of self-presentation is central. Media practices reflect how people construct who they are and how they relate to others. Identity practices are socially constructed, so when individuals alter between identification and dis-identification, their identities are subject to change. Social and technological affordances have given rise to create new performances of online identity (p. 10). Multiple semiotic modes play a crucial role in identity construction and negotiation.

Petroni (2019, p.259) defines identity construction as a public process that involves identity announcement (made by the individual) and identity placement (made by others who stress the assumed identity by means of establishing a digital connection). 
(ISSN : 2536 - 9555)

As digital discourse studies have created a new type of sociolinguistic awareness, the main objective of the present study is to examine how the new digital discourse has given rise to new modes of constructing Mansoura University identity. In other words, the study aims to elaborate on the way Mansoura University identity is constructed digitally. One main research question here is: what are the linguistic dimensions of constructing the identity in a digital sitting as a form of a social practice?

\section{Review of the literature}

The present study investigates the way the new digital world has given rise to a type of digital discourse that is service-oriented to underpin ideologies and identity of web users (either individuals or institutions). In the literature, there are many attempts to discuss how media practices shape people's identities and relations to others: for example, Garcés- Conejos Blitvich (2010), GarcésConejos Blitvich, \&Bou-Franch (2011), Thurlow \& Mroczek (2011), Page (2012), Garcés- Conejos Blitvich, Bou-Franch, \& Lorenzo-Dus (2013), Tag\& Seargeant (2014) and Bolander\& Locher (2015) among others. The review of the literature here focuses on summing up the main assumptions about the relationship between language, in the new media, and identity replications. It is restricted to the following two main references that provide an orchestrated perspective on digital discourse and the language of media: (1) Holmes (2006) which tackles how identities are shaped in professional settings. (2) Jones, Chick \& Hafner (2015) which tackle how technology alters the way people communicate and interact and discusses the nature of digital discourse taken to be a new language in new media.

\subsection{Holmes (2006)}

Recognizing narration as an important means of identity construction, Holmes (2006) investigates the way workplace anecdotes contribute to the development of people's professional identities at work. She argues that research on the different theories of social identity has revealed a close relationship between the 
Discourse and Identity in the Digital World: Mansoura University Website as a Model

Dr. Rehab Farouk Gad

$$
\text { مجلة وادي النيل للاراسات والبحوث الإنسانية والاجتماعية والتربوية (مجلة علمية محكمة) }
$$

identities of individuals and the identities of their group. Social identity theory considers people's group identifications as fundamental to the development of their self- image which justifies the way they linguistically behave. The idea that an individual could assume multiple identities is also discussed where it is believed that anyone can have a social identity, which links $\mathrm{him} / \mathrm{her}$ to a social group, and a personal identity, which is revealed in face-to-face interactions with people. Certain aspects of people's social identity are stressed to emphasize gender, ethnicity, authority, power, professional status or institutional and organizational identity (p. 167).

Holmes (2006) believes that the complexity of people's identities is constructed in the workplace where anecdotes, distinguished from business talks by virtue of being interesting and entertaining, play a pivot role in shaping their professional identities. The language employed in workplace anecdotes sustain and bring about public-private interface. A linguistic analysis of the features of the interpersonal interactions in different workplaces in New Zealand is offered by Holmes (2006) based on data collected from different tape and video recordings of these interactions. One of the interesting examples given is a conversation between a female manger and a male employee. Recognizing how the employee had acted stupidly, the manager decided to hear the story from him, who in turn thought the conversation to be so friendly and explained what he exactly did. To encourage the employee to speak up, the manager first assumed the role of an innocent observer; however, coming across the truth, she wickedly mimicked the employee's response and assumed the role of a tough manager. Holmes concludes that workplace anecdotes create a sense of solidarity, or creating team (p. 186). Workplace anecdotes are reflecting the different aspects of people's identity and "provide an important interface between the personal and public dimensions of an individual's socio-cultural identity" (p. 186). 
مجلة وادي النيل للاراسات والبحوث الإنسانية والاجتماعية والتربوية (مجلة علمية محكمة)

(ISSN : 2536 - 9555)

\subsection{Jones et al (2015)}

Jones et al (2015) discuss digital technology which has offered people different ways to communicate and establish relationships. This offered new insights into the way language is employed in texts and in social interactions. Digital media have facilitated the production of multimodal texts such as blogs and network sites that guarantee a type of interaction, different from face-to-face conversations and written texts. Within the frame of digital technology, analytical tools that underpin discourse ideological dimensions are modified to handle "discursive environments in which the loci of power are much more diffuse and the instruments of ideological control and disciple are more subtle and complex" (p.1). Jones et al use the term digital practice to refer to relationships, events, actions and places that involve real people. Digital practices, such as 'tagging', involve different actions carried out by different people in different contexts (e.g. Twitter vs Flickr). These practices normally alter to adapt to the new cultural tools, and overlap with other practices, such as dieting (MyFitnessPal) and socializing (Club Penguin Music Video Production). Digital practices are contained within other cultural practices via some levels and actions to present sequences of actions and shape social identities. What digital practices refer to are the actions which involve the use of digital technology by certain group of people to achieve social targets, highlight social identity, and sustain social relationships. In sum, digital practices which include, in addition to software and websites, physical artifacts such as iPhones and iPads, have offered new social practices and changed the way people used to engage in old ones (p.3). These practices have transcended the boundaries between technological systems and social systems. Accordingly, the concept of discourse is narrowed down to a type of social practices or a tool for carrying out social practices. Discourse is dealt with as a study of how technologies of entextualization (e.g. language as a semiotic system and Television and computers as types of media) influence the way people act and form relationships with others 
Discourse and Identity in the Digital World: Mansoura University Website as a Model

Dr. Rehab Farouk Gad

$$
\text { مجلة وادي النيل للاراسات والبحوث الإنسانية والاجتماعية والتربوية (مجلة علمية محكمة) }
$$

and the identities they assume. Within this frame of defining Discourse Analysis, four main aspects are the focus (p. 4):

1. Texts: how texts are formed by different technologies of entextualisation in order to perform certain actions that are socially recognized

2. Contexts: the situations in which texts are formed, used or exchanged

3. Actions and interactions: how people use texts especially when they interact

4. Power and ideology: how texts are manipulated to control others and become reflections of reality

Jones et al (2015) claim that the main approaches to discourse aim at investigating the kind of relationship between the micro levels of discourse, which refer to the way texts are compiled together to perform certain actions in certain situations, and the macro levels that illustrate how texts represent some social orders. Websites, which are the main focus of the present study, are dealt with as a type of text that uses language as a semiotic tool to carry out certain social actions.

\section{Theoretical framework}

As reviewed in section 2, Jones et al (2015) have associated some tools (e.g. websites, hardware, physical objects and other semiotic tools of talking or writing in digital media) with digital technology. In the present study, tools are excerpts with written texts extracted from a website of an educational institution (i.e. Mansoura University). In this section, I sum up the main tenets of two theoretical frameworks that account for the way digital language presents and projects identity within the textual world of the internet: Darvin (2016) and Petroni (2019).

\subsection{Darvin (2016)}

The world has witnessed a rapid and exciting transformation where technology has facilitated communication and social interaction. Nations of both public and private domains have also 
(ISSN : 2536 - 9555)

been dramatically transformed. Such type of transformation encompassed language and identity. New genres, vocabularies and styles are triggered and introduced by the digital age where new words that fit into the interactive nature of speech are produced. The new media, initiated by the digital revolution, facilitate integrated language that is characterized by inhibiting visual, aural, gestural and spatial modes (p. 524). In addition to language transformation, identity has also been transformed, thanks to the digital, and is shaped and formulated through language which conveys our ideas and hence represents our social reality and relations.

Users of the digital media need to gain access to the digital world in order to identify and confirm their position in the technologized world (p. 525). Darvin (2016) adds that technology has induced a transformation in the social order; accordingly, a shift in language and identity practices is recognized. Following Cope and Kalantzis (2012), Darvin (2016) argues that digital media enhance the concepts of Agency, Divergence, Multimodality and Conceptualization. Digital media have created a type of affordances especially in the area of agency which refers to how users behave, speak, see and act to create their own identity. What is meant is that users of the digital media can differentiate themselves by the language they utilize. Individual agency refers to the ability to represent the self in the digital media where language has become similar to that used in face-to-face interaction. Written texts can now be interpreted in interactional and dialogic ways. Digital discourse makes good use of videos, images and visual effects. With divergence, Darvin means that users participate in a wide range of online communities, with each community formulating its own language practices. This has negatively influenced intelligibility between the users and these communities, so less intelligible discourses are witnessed. This explains why divergence has become an issue to be concerned. Multimodality refers to the availability of a variety of modes (e.g. videos, music, images, etc.) that allows more space for self-presentations. Conceptualization has become a necessity to develop new ways of 
Discourse and Identity in the Digital World: Mansoura University Website as a Model

Dr. Rehab Farouk Gad

$$
\text { مجلة وادي النيل للاراسات والبحوث الإنسانية والاجتماعية والتربوية (مجلة علمية محكمة) }
$$

thinking and produce more attractive media texts. So, agency, divergence, multimodality and conceptualization are all products of digital media.

\subsection{Petroni (2019)}

Following Fairclough (1992, 1995), Petroni (2019) discusses the process of 'informationalization' of the public discourse. This process has transformed both the style and the register enacted within different communicative practices reinforcing the initiation of new digital media. Following the advent of the new digital media, all official and business situations have reshaped their own styles to underpin their own identity within local and global domain practices. The web is described as a hyperdomain (Petroni 2019, p. 252) due to its collaborative and sharable nature. Information displayed on the web is dealt with as a commodity that has to be both informative and persuasive. So, Petroni (2019) adds that "persuasive, evaluative and descriptive rhetorical actions, characterizing promotional genres and settings, are often present and integrated in the meaning-making process on the web, be it instantiated in a site or an interface"(p. 253). For Petroni (2019), most social network environments aim at selfprofiling. Both self-promotion (which is an integral part of selfidentity) and self-branding (e.g. reputation and networking) construct commodified identities.

Digital technology has become a persuasive technology that affects the habits and the values of the users and encourages them, within algorithmic frameworks, to adopt precise behaviors. So, digital technology changes any product into a desirable one. Creators of digital artifacts work on the attitudes and behaviors of the users who, by just one simple click, sign up for services. Social media stress the value of information and help users construct their own world and identities. Petroni also examines how users present themselves in a professional digital environment and discusses the way LinkedIn shapes and constructs identity; the way these identities perform with other social connections is also discussed. 
(ISSN : 2536 - 9555)

Web 2.0 is a functional platform that helps its users engage in a more global form of communication. Actions carried out by users of web 2.0 (i.e. personal profiles, blogs, Facebook, Twitter, LinkedIn, Instgram, YouTube) reshape and reconstruct their identities. As for the idea of self-presentation being a way of projecting an online identity, Petroni argues that in a global openaccess environment, users are no longer isolated personae, but rather 'networked slaves' who attempt to impress others. The concept of reputation is closely related to that of self-presentation. Social networks are defined as a popular media of self-expression and self- promotion. While Facebook facilitates self-presentation, LinkedIn is a self- promotion platform. In web 2.0, some strategies of self- branding enhance reputation building and highlight social network profiles. Web 2.0 facilitates search engine and provides accessible techniques to find one's information. Popularity and connectivity are another two concepts discussed by Petroni (2019). Digital platforms boost the popularity of people, things and ideas. Online popularity is reflected by the number of most viewed profiles in LinkedIn, friends' state in Facebook and number of followers in Twitter (p.263). The idea of connectivity, which links content to the activities of the users, involves participation, connectedness, and technical valence.

\section{Data Collection and Analysis}

Labrecque, Markos \& Milne (2011) argue that when people are using search engine techniques to facilitate accessing their information on web 2.0 , social profiles are maintained and identity building is brought about. Web 2.0 is a modification of the way web pages are designed and used. It is a participation- facilitating social web that highlights user- generated content (Blank \& Reisdorf, 2012). Identity, on the other hand, is defined by Norton (2013) as a way a person establishes his/her relationships to the world, how he/she views these relationships and understands possibilities for the future. The present study proposes a multimodal approach (following Darvin 2016) to the digital identity of Mansoura University (henceforth, MU) on web 2.0 
Discourse and Identity in the Digital World: Mansoura University Website as a Model

Dr. Rehab Farouk Gad

$$
\text { مجلة وادي النيل للاراسات والبحوث الإنسانية والاجتماعية والتربوية (مجلة علمية محكمة) }
$$

which is constructed by manipulating language-oriented tools in addition to other modes such as images, sounds, and videos. The study also investigates how different activities (educational, social, cultural etc.), carried out by MU, are in fact converted to a digital language. The data employed as the basis of the analysis in this study are extracted from large database of announcements, texts and images displayed on MU website in 2020 (following the widespread transmission of Covid-19). Data were analyzed in two phases: first, data were classified and categorized based on the content of the written text of each excerpt; second, data were analyzed and observations and remarks were subsequently drawn.

\subsection{Categorization of Data}

In phase one, the selected excerpts are distributed into three categories: educational (academic), social and international (in appendix A, each excerpt is followed by its suggested translation). The main assumption here is that each category is actually representing a separate identity. Within each category (identity type), expressions, which signify impression management and reputation building and promote identity constructions are extracted. The most frequently used nouns (e.g. nouns which have referential and prootional meanings), verbs and adjectives are highlighted to illustrate how these linguistic tools (in addition to non-linguistic tools of digital media such as videos and images), enhance self-representation, self-reputation, self-profiling and selfpromotion as suggested by Petroni (2019). Data are distributed in the following three tables, followed by a proposed analysis of the digital discourses of the written texts:

\subsubsection{Educational Identity}

The main argument of the present study is that MU assumes multiple identities. By language-oriented tools, implications on attitudes and ideologies are drawn. In table 1 below, a sample of educational news, achievements and announcements displayed on MU website is explained. 
(ISSN : 2536 - 9555)

Table 1 Educational excerpts and remarks

\begin{tabular}{|c|c|}
\hline $\begin{array}{l}\text { Excerpt } \\
\text { Number }\end{array}$ & Remarks \\
\hline 1 & $\begin{array}{l}\text { It is the home page of The Egyptian Journal of Basic and Applied } \\
\text { Sciences (EJBAS) which is the official publication of MU. This journal } \\
\text { is published by MU in collaboration with Elsevier. The home page of } \\
\text { Mansoura Journal of Environmental Sciences - Egypt (JOESE) is } \\
\text { given in excerpt (1b). }\end{array}$ \\
\hline 2 & $\begin{array}{l}\text { It displays an important announcement for upcoming workshop } \\
\text { organized by Projects Management Unit at University Development } \\
\text { Center. }\end{array}$ \\
\hline 3 & $\begin{array}{l}\text { It announces for the implementation of online portal project which } \\
\text { illustrates the attempt of MU to gain a digitized educational identity } \\
\text { adapted to the } 2020 \text { Covid } 19 \text { precautions. }\end{array}$ \\
\hline 4 & $\begin{array}{l}\text { It presents QUALITY of teaching and education as central to the } \\
\text { criteria upon which MU is ranked both nationally and internationally. } \\
\text { MU has devised Al-Farabi system to handle Teaching and Learning } \\
\text { Quality Administration. }\end{array}$ \\
\hline 5 & $\begin{array}{l}\text { It displays quick links to a series of workshops on different topics such } \\
\text { as websites 'development and content management, among others. }\end{array}$ \\
\hline 6 & $\begin{array}{l}\text { It introduces a special unit located at the Faculty of Agriculture. It } \\
\text { offers scientific research services to MU as well as other Arab } \\
\text { universities in the region. Services are limited to areas of } \\
\text { nanotechnology, physics, semiconductors and Biology. }\end{array}$ \\
\hline 7 & $\begin{array}{l}\text { It announces for MU being ranked THE FIRST in a competition of } \\
\text { digital transformation among other Egyptian universities. }\end{array}$ \\
\hline 8 & $\begin{array}{l}\text { It displays quick links to the services provided by the Communications } \\
\text { and Information Technology Centre located at the main campus of } \\
\text { MU. Examples of these services include, but not limited to: } \\
\text { - } \quad \text { access to Ibn Al-Haitham System for postgraduates } \\
\text { - } \quad \text { clinic appointments } \\
\text { - } \quad \text { hospitals management } \\
\text { - } \text { access to United Kingdom libraries }\end{array}$ \\
\hline 9 & $\begin{array}{l}\text { It presents example of competitions held among different libraries of } \\
\text { MU such as central library, libraries of different faculties and libraries } \\
\text { of different medical centres at MU. Such competitions aim at } \\
\text { promoting cultural activities. }\end{array}$ \\
\hline 10 & $\begin{array}{l}\text { It is an announcement of the success of a twin delivery operation of a } \\
\text { Covid- } 19 \text { female patient on the } 21^{\text {st }} \text { of October } 2020 \text { at MU } \\
\text { Emergency Hospital which provides free medical services to residents } \\
\text { of Mansoura city. As illustrated by the excerpt, all Covid-19 } \\
\text { precautions are strictly applied in the intensive care units in MU } \\
\text { Emergency Hospital. }\end{array}$ \\
\hline
\end{tabular}


Discourse and Identity in the Digital World: Mansoura University Website as a Model

Dr. Rehab Farouk Gad

مجلة وادي النيل للاراسات والبحوث الإنسانية والاجتماعية والتربوية (مجلة علمية محكمة)

One of the main observations about MU website is that by the time data were collected, (from January to December 2020), the website was available only in Arabic, though announcements of academic events and publications are presented in English. This indicates the tendency of the university towards placing itself among other world universities via publications of international journals and research papers (as in excerpts $1 \mathrm{a} \& 1 \mathrm{~b}$ ).

It is also observed that most of the announcements in excerpts (1-9) focus on the academic contributions of MU as a whole, rather than on the contributors themselves. For example, the headline in excerpt (10) is: جامعة المنصورة تتجح في و لادة تو أم لسيدة مصابة a بفيروس كورونا operation of a Covid -19 female patient”.

So, the educational identity of MU as an institution actually diverges from the different institutionalized identities of its administration board (president, vice presidents, board of trustees, etc.), staff members, employees and students. This has resulted in a remarkable institutional change exemplified in excerpts (16-17, table 3) which announce the rankings of MU both nationally and internationally. Opposite assumptions about multiple identities being a trigger for embedded agency and negative institutional change are discussed by Horton and Wanderley (2018).

\subsubsection{Social Identity}

A second type of identity representation assumed by $\mathrm{MU}$ is social identity. Excerpts which reflect the role of MU as a social service provider are explained in the following table, followed by remarks and observations. 
مجلة و ادي النيل للاراسات والبحوث الإنسانية والاجتماعية والتربوية (مجلة علمية محكمة)

(ISSN : 2536 - 9555)

Table 2 Social excerpts and remarks

\begin{tabular}{|c|l|}
\hline $\begin{array}{c}\text { Excerpt } \\
\text { Number }\end{array}$ & \multicolumn{1}{|c|}{ Remarks } \\
\hline $\mathbf{1 0}$ & $\begin{array}{l}\text { It is an announcement of the success of a twin delivery operation of } \\
\text { a Covid- 19 female patient on the } 21^{\text {st }} \text { of October } 2020 \text { at MU } \\
\text { Emergency Hospital which provides free medical services to } \\
\text { residents of Mansoura city. As illustrated by the excerpt, all Covid- } \\
19 \text { precautions are strictly applied in the intensive care units in MU } \\
\text { Emergency Hospital. }\end{array}$ \\
\hline $\mathbf{1 1}$ & $\begin{array}{l}\text { We come across other social services provided by MU: free online } \\
\text { traineeships in the fields of employment skills, customer service, } \\
\text { occupational health and safety, sales\& marketing etc. }\end{array}$ \\
\hline $\mathbf{1 3}$ & $\begin{array}{l}\text { Similar traineeships in the field of health awareness are held as } \\
\text { indicated here where lectures on swine flu and SARS are announced } \\
\text { for. }\end{array}$ \\
\hline $\mathbf{1 4}$ & $\begin{array}{l}\text { It presents a YouTube video which introduces services provided by } \\
\text { Child Welfare and Development Centre located in the main campus } \\
\text { of MU and funded by it. The Video, posted also on Facebook and } \\
\text { Twitter, is employed here as one of the digital tools targeting } \\
\text { identity presentation. }\end{array}$ \\
\hline $\begin{array}{l}\text { It presents some of the medical services presented to MU students } \\
\text { through Medical Clinics and the Students Hospital. In this excerpt, } \\
\text { another digital tool (e.g., attractive images) is used. One of the } \\
\text { images is of a tired face of a young adult, putting a compress on the } \\
\text { forehead and a thermometer next to him as indications of fever (a } \\
\text { main symptom of Covid-19). }\end{array}$ \\
$\begin{array}{l}\text { It indicates, a further social role played by MU, stressing its social } \\
\text { identity, is that of women's rights advocate. It is not clear whether } \\
\text { the target women here are female residents of Mansoura City, or } \\
\text { female students, employees, and staff members of MU. One } \\
\text { possible reason for not specifying the target women is to magnify } \\
\text { the social role of MU as an advocate of the rights of All Women. }\end{array}$ \\
\hline
\end{tabular}


Discourse and Identity in the Digital World: Mansoura University Website as a Model

Dr. Rehab Farouk Gad

\section{مجلة وادي النيل للاراسات والبحوث الإنسانية والاجتماعية والتربوية (مجلة علمية محكمة)}

One of the main concepts of sociology is social capital defined by Bourdieu and Wacquant (1992, p. 14) as the group of actual or virtual resources that are accumulated to establish institutionalized relationships among groups. According to Helliwell and Putnam (2004), social capital is a positive outcome of interaction among a group of participants in a social network. Social relationships and structures are maintained when social capital is achieved. Accordingly, social identities are sustained and enhanced if such social capital is well established. Considering the information presented on MU website, it is argued here that such information is linguistically presented for better targeting of the promotion of a social capital that MU attempts to establish with Mansoura community, on one hand, and with other institutions, on the other hand. A sustained social capital has positive social outcomes; for example, it encourages a commitment of MU towards Mansoura community. Looking at the information given in excerpts (10-15), it could be argued that MU presents itself on the digital media as a social services provider where the target customers are: an expected mother with Covid-19 (excerpt 10), unemployed graduates (excerpt 11), people seeking knowledge on evironmental awareness of infectious diseases (excerpt 12), parents interested in child care services (excerpt 13), students with signs or symptoms of Covid-19 (excerpt 14), communities combating violence against women (excerpt 15).

Such variety of social services encourages community interactions and guarantee involvement as suggested by Ellison, Steinfeld and Lampe (2007). Internet-based linkages sustain weak ties and build new relations and new forms of social capital. Digital language employed in these social service-based announcements highlight an identity representation of attitudes and ideologies of an institution keen on sharing common interest with the whole community of Mansoura city. Linguistic analysis is proposed in section 4.1.4. 
(ISSN : 2536 - 9555)

\subsubsection{International Identity}

International identity is the third type of identity representation MU is said to assume. Excerpts which reflect the image of MU, nationally and internationally, on the internet, is explained in the following table, followed by remarks and observations.

Table 3 International excerpts and remarks

\begin{tabular}{|c|l|}
\hline $\begin{array}{c}\text { Excerpt } \\
\text { Number }\end{array}$ & \multicolumn{1}{|c|}{ Remarks } \\
\hline $\mathbf{1 6}$ & $\begin{array}{l}\text { It illustrates the world university rankings by Times } 2020 \text { for } \\
\text { emerging economies where MU is ranked THE FIRST in } \\
\text { Egypt. The rankings of universities posted on the American } \\
\text { website U.S News are given in excerpt (17). }\end{array}$ \\
\hline $\mathbf{1 7}$ & $\begin{array}{l}\text { As explained in this excerpt, the ranking of MU among other } \\
\text { Egyptian, African and international universities depends } \\
\text { mainly on the criteria for evaluating scientific research } \\
\text { bibliometrics for analyzing contents of research and the } \\
\text { references used. }\end{array}$ \\
\hline $\mathbf{1 8}$ & $\begin{array}{l}\text { It displays the scholarships granted for MU postgraduate } \\
\text { students through international academic institutions and } \\
\text { universities. The scholarships exemplify efforts exerted by } \\
\text { MU to ensure the best quality of education and at the same } \\
\text { time to sustain its international identity }\end{array}$ \\
\hline $\mathbf{1 9}$ & $\begin{array}{l}\text { Excerpt (19) features an important cornerstone of MU } \\
\text { educational, social and international identity and one of the } \\
\text { main university hospitals in the Arab region and in the world; } \\
\text { that is the Urology \& Nephrology Centre. In this medical } \\
\text { institution, data are collected, statistically analyzed and } \\
\text { internationally published in world top medical journals. The } \\
\text { center provides Egyptian and international medicine students } \\
\text { and postgraduates intensive training on surgical procedures. } \\
\text { The center gains its international reputation due to the highest } \\
\text { success rate of the laparoscopic surgeries it conducts. }\end{array}$ \\
\hline
\end{tabular}


Discourse and Identity in the Digital World: Mansoura University Website as a Model

Dr. Rehab Farouk Gad

$$
\text { مجلة وادي التيل للار اسات والبحوث الإنسانية والاجتماعية والتربوية (مجلة علمية محكمة) }
$$

As illustrated in the above table, two excerpts (16 \&17) display the ranking of MU in the field of emerging economies and its ranking among Egyptian, African and international universities in 2020. Visitors to MU website are not addressed in the customary language, for example, the language of media and press, but rather in a digital language, which relies on some digitalized information such as number of visitors, and other statistics. In excerpt (16), MU is ranked THE FIRST for emerging economies in Egypt. By the time excerpt (17) was captured from MU website, the number of visitors was 860 and statistics about MU rankings among Egyptian universities (number 2), African universities (number 9) and International universities (number 547) were digitally presented.

Reputation, similar to self-representation, is derived from perception, approval, and attention, as argued by Petroni (2019, p. 258). To build a reputation, both image making and impression management should constantly be adapted to the situation. Contextual, institutional and cultural factors work together to highlight achievements and hence, signify reputation. Referring back to the remarks drawn from excerpt (19) in table (3), it is observed that the Urology \& Nephrology Centre, which is basically a medical and educational institution, is the only medical centre to be introduced in English on the website, though other educational, research and medical institutions have subsequently joined up, resulting in MU merging to the digital space. Information about the research activities and the international medical services provided by the Urology \& Nephrology Centre is disseminated here in English to respond to international and scientific research challenges and at the same time promote the international identity of MU.

\subsubsection{Linguistic Tools of Self- Profiling and Identity Construction \\ According to Rodden (2006), there are some online} techniques that can be used to highlight the quality of achievements: for example, opinion expressions, values 
(ISSN : 2536 - 9555)

expressions, connection enhancement expressions. In this section, linguistic structures and expressions which achieve the purpose of self-profiling, self-promotion and identity construction are extracted and analyzed following the work of Petroni (2019) which is adopted as one of the theoretical frameworks of the present study. Items that reflect issues of identity are extracted from the sample of the study and divided into the three grammar classes normally employed when uploading information to a website: nouns, verbs and adjectives. The extracted items are then classified into items of referential meaning, and items of promotional meaning as illustrated by tables (4) and (5) respectively:

Table 4 Referential items

\begin{tabular}{|c|c|c|c|c|}
\hline & Excerpt n. & Identity Type & Referential item & Word class \\
\hline 1 & \multirow{8}{*}{$1 \mathrm{a}$} & \multirow{8}{*}{ Educational } & Journals & noun \\
\hline 2 & & & Books & noun \\
\hline 3 & & & Content & noun \\
\hline 4 & & & Issues & noun \\
\hline 5 & & & Register & verb \\
\hline 6 & & & Sign in & verb \\
\hline 7 & & & Explore & verb \\
\hline 8 & & & view & verb \\
\hline 9 & \multirow{7}{*}{2} & \multirow{7}{*}{ Educational } & اعلان announcement & noun \\
\hline 10 & & & administration & noun \\
\hline 11 & & & المشروعات projects & noun \\
\hline 12 & & & experiences تجارب & noun \\
\hline 13 & & & qualifications شهادات & noun \\
\hline 14 & & & شروط criteria & noun \\
\hline 15 & & & performance & noun \\
\hline 16 & \multirow[b]{3}{*}{3} & \multirow[b]{3}{*}{ Educational } & مشروع project & noun \\
\hline 17 & & & implementation انشاء implention & noun \\
\hline 18 & & & portal & noun \\
\hline
\end{tabular}


Discourse and Identity in the Digital World: Mansoura University Website as a Model

Dr. Rehab Farouk Gad

مجلة وادي النيل للاراسات والبحوث الإنسانية والاجتماعية والتربوية (مجلة علمية محكمة)

\begin{tabular}{|c|c|c|c|c|}
\hline 19 & & & acknowledged و افقت & verb \\
\hline 20 & & & represented تتمثل repred & verb \\
\hline 21 & \multirow{5}{*}{11} & \multirow{5}{*}{ Social } & announcement اعلان & noun \\
\hline 22 & & & scholarships & noun \\
\hline 23 & & & employment توظيف emp & noun \\
\hline 24 & & & health الصحة health & noun \\
\hline 25 & & & administration ادارة & noun \\
\hline 26 & \multirow[t]{2}{*}{13} & \multirow[t]{2}{*}{ Social } & video & noun \\
\hline 27 & & & مركز center & noun \\
\hline 28 & \multirow[t]{7}{*}{14} & \multirow[t]{7}{*}{ Social } & طلابنا our students & noun \\
\hline 29 & & & عياده clinic & noun \\
\hline 30 & & & طبية medical & adjective \\
\hline 31 & & & tired تعبان tired & adjective \\
\hline 32 & & & اءواء procedures اجر & noun \\
\hline 33 & & & التزم stick to & verb \\
\hline 34 & & & احمي protect & verb \\
\hline 35 & \multirow{7}{*}{15} & \multirow{7}{*}{ Social } & عنف violence & noun \\
\hline 36 & & & المرأة women & noun \\
\hline 37 & & & policies & noun \\
\hline 38 & & & apply تطبق & verb \\
\hline 39 & & & تتبنى adopt & verb \\
\hline 40 & & & ام general عام & adjective \\
\hline 41 & & & harassment التحرش & noun \\
\hline 42 & \multirow{5}{*}{$1 \vee$} & \multirow{5}{*}{ International } & ranking ترتيب rang & noun \\
\hline 43 & & & analysis تحليل & noun \\
\hline 44 & & & $\begin{array}{l}\text { أعلأinnounced/declared } \\
\text { annoli }\end{array}$ & verb \\
\hline 45 & & & جاءت came & verb \\
\hline 46 & & & صنفتْ & verb \\
\hline
\end{tabular}


مجلة وادي النيل للاراسات والبحوث الإنسانية والاجتماعية والتربوية (مجلة علمية محكمة)

(ISSN : 2536 - 9555)

Table 5 Promotional items

\begin{tabular}{|c|c|c|c|c|}
\hline- & Excerpt n. & Identity Type & Referential item & Word class \\
\hline 1 & \multirow[t]{2}{*}{$1 \mathrm{a}$} & \multirow[t]{2}{*}{ Educational } & active & adjective \\
\hline 2 & & & latest & adjective \\
\hline 3 & \multirow{13}{*}{2} & \multirow{13}{*}{ Educational } & تطوير development & noun \\
\hline 4 & & & laccreditation & noun \\
\hline 5 & & & education التعليم & noun \\
\hline 6 & & & سمعة reputation & noun \\
\hline 7 & & & ناجحة successful & adjective \\
\hline 8 & & & experience & adjective \\
\hline 9 & & & Sتمدة accredited & adjective \\
\hline 10 & & & متميزة distinguished & adjective \\
\hline 11 & & & previous & adjective \\
\hline 12 & & & مهنية professional & adjective \\
\hline 13 & & & علمية scientific & adjective \\
\hline 14 & & & هام & adjective \\
\hline 15 & & & سابقة previous & adjective \\
\hline 16 & 3 & Educational & أهم most important & adjective \\
\hline 17 & \multirow{6}{*}{11} & \multirow{6}{*}{ Social } & مهار ات skills & noun \\
\hline 18 & & & جودةد quality & noun \\
\hline 19 & & & خدمة services & noun \\
\hline 20 & & & تدريبية training & adjective \\
\hline 21 & & & متاحة $\quad$ available & adjective \\
\hline 22 & & & مجانية free & adjective \\
\hline 23 & \multirow{3}{*}{13} & \multirow{3}{*}{ Social } & care رعاية care & noun \\
\hline 24 & & & development & noun \\
\hline 25 & & & تعريفي introduction & adjective \\
\hline 26 & 14 & Social & lear الأعزاء dear & adjective \\
\hline 27 & \multirow{8}{*}{15} & \multirow{8}{*}{ Social } & تدابير measures & noun \\
\hline 28 & & & معاقبة punishing & noun \\
\hline 29 & & & sexual الجنسي sexul & adjective \\
\hline 30 & & & خاص special & adjective \\
\hline 31 & & & clear & adjective \\
\hline 32 & & & محددة decisive & adjective \\
\hline 33 & & & combating مناهضة comb & adjective \\
\hline 34 & & & متحرش harasser & adjective \\
\hline 35 & \multirow{6}{*}{17} & \multirow{6}{*}{ International } & global العالمي gl & noun \\
\hline 36 & & & level مستوى level & noun \\
\hline 37 & & & group مجمو عة group & adjective \\
\hline 38 & & & متنو عة varied & adjective \\
\hline 39 & & & academic & adjective \\
\hline 40 & & & جامعية university & adjective \\
\hline
\end{tabular}


Discourse and Identity in the Digital World: Mansoura University Website as a Model

Dr. Rehab Farouk Gad

$$
\text { مجلة وادي النيل للاراسات والبحوث الإنسانية والاجتماعية والتربوية (مجلة علمية محكمة) }
$$

The study here categorized the items listed in tables 4 and 5 into referential items (words most commonly occur in academic contexts and reflect no subjectivity or personal inclinations) and promotional items (words most commonly occur in marketing and advertising). In table 4, the total number of referential items is 46 : 30 nouns, 13 verbs and 3 adjectives. In table 5, the total number of promotional items is 40: 13 nouns, 0 verb and 27 adjectives. It is observed that the number of nouns outweighs that of verbs and adjectives. The number of verbal nouns also outweighs that of content words: for example, تصنيف "rating” not يصنف "to rate”,

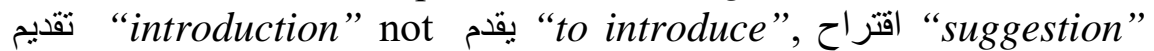
not يقترح "to suggest”, تطوير “development” not يطور “to "to " develop", انشاء “implementation" not "to implement”. In marketing and advertising, verbal nouns are the latest tools employed to invite consumers to think, participate and respond. The excessive use of verbal nouns in MU website has contributed to the transformation of the information posted on the web into a type of commodity as will be argued later in section 4.2.2.

The linguistic analysis proposed here could not ignore the ideational and propositional functions of language. Jones and Hafner (2012, p. 104) argue that language forms a proposition to express ideas about reality. It is well known that Mansoura city is widely acknowledged as the capital of medicine in Northern Egypt; it was also introduced to the whole world through Urology\& Nephrology Centre at MU. As illustrated by excerpt (19), the center was established in 1970s as both clinic and academic services provider with international fame. The ideational language of the English text in excerpt (19) forms a proposition to express ideas about reality as the text here reflects an agenda of the teamwork in Urology\& Nephrology Centre distinguished at different medical specialties such as radical cystectomy, urinary diversion, and pediatric urology. 
مجلة وادي النيل للاراسات والبحوث الإنسانية والاجتماعية والتربوية (مجلة علمية محكمة)

(ISSN : 2536 - 9555)

\subsection{Analysis of the Selected Digital Discourses}

The language of the digital world is subject to continuous changes as new styles and genres are introduced. People can now assume different identities as they can move smoothly across offline and online domains; hence, it can be argued, following Darvin (2016), that digital discourse and identity are both Dynamic. Having assumed that the language of the written texts displayed on MU website is a type of digital language that exhibits the main features of digital discourse, the following features, discussed in Jones \& Hafner (2012), Müller (2017) and Petroni (2019), are investigated: (1) digital discourse is informative; (2) digital discourse is persuasive; (3) digital discourse is informal.

\subsubsection{Informative Digital Discourse}

In the field of advertising, being informative necessitates a direct and precise presentation of information. What advertisers wish to achieve is to give a clear image of the features and qualities of the commodity and to implicitly convince the consumers and to change their attitudes by just a simple click. The major claim of the present study is that information is a type of commodity, and that language styles have to adapt to the information they convey. Hence it is expected to encounter informative language that relies on numbers and dates when advertising for educational and academic activities on MU website: examples of informative language are listed below:

1. Latest publications of the Egyptian Journal of Basic \& Applied Sciences, number of issues and volumes in excerpt (1a)

2. Positions available for staff members at the UDC and the job specifications in excerpt (2)

3. Information about projects' teams, important dates and deadlines in excerpt (5)

4. List of cultural activities and their time, date and venue in excerpt (9)

5. Lectures in environmental and health awareness and their time, date and venues in excerpt (12)

6. States of missions and scholarships in excerpt (18) 
Discourse and Identity in the Digital World: Mansoura University Website as a Model

Dr. Rehab Farouk Gad

مجلة وادي النيل للاراسات والبحوث الإنسانية والاجتماعية والتربوية (مجلة علمية محكمة)

\subsubsection{Persuasive Digital Discourse}

A main characteristic of the digital language is its similarity to the language of advertisements that seeks to create an intimate relationship with consumers. When buying a certain product, consumers need to know more about is quality, features, reliability, availability, and most importantly, its price. The website under investigation here is acting as the advertising portal that spreads information on the educational and social services provided by MU. Looking at information as a commodity (as argued earlier), a subsequent phase of marketization is expected and reputation, which is a cultural product of digital discourse, is accordingly built. Information displayed on websites reflects a type of promotional culture (a term used by Petroni 2019, p. 259), where goods, people, services are all part of this culture. MU is constructing its own identity within the competitive needs of the market via the information displayed on its website, which is actually acting as a promotional advertising platform as indicated by the following remarks on some excerpts:

1. Posting the video in excerpt (13) has a persuasive purpose. It affects people's behaviors and attitudes: if parents are not interested to know about the services provided by Child Welfare \& Development Centre, they can at least tell a friend about it.

2. In excerpts $(16 \& 17)$, announcement of the RANKINGS of MU is a persuasive and promotional tool that invites international students to join up in a highly ranked academic institution. Capitalization is a degree of intensification Language mostly appropriately used in similar contexts.

3. In excerpt (18), foreign educational scholarships are advertised for, followed by number of visitors to the website who viewed the announcement and read the requirements of the scholarships. Displaying the number here is a marketing and persuasive strategy that stimulates quick response and participation. 
مجلة وادي النيل للاراسات والبحوث الإنسانية والاجتماعية والتربوية (مجلة علمية محكمة)

(ISSN : 2536 - 9555)

Capitalization is also used with reference to the universities: POLITECNICO DI TORNO, Italy \& SCUOLA NORMALE DI PISA, Italy

\subsubsection{Informal Digital Discourse}

To be more accessible and user-friendly, language of the written texts of digital discourse tends to be informal. Jones and Hafner (2012, p. 105) consider informal language as a trigger of the sense of intimacy. Darvin (2016, p. 524) describes digital language as being a sort of integrated language that achieves multimodality by means of excessive use of visual and gestural modes. The relationship between digital discourse and agency is discussed by Cape and Kalantzis (2010) who argue that users of the digital media represent themselves by using a kind of informal language characteristic of face-to-face interaction. Example of this language style appears on MU website when addressing undergraduates. In excerpt (14), copied below, text and picture combination is used to contribute to the interpretation of the important message it conveys: a quick response to sudden signs of Covid-19.

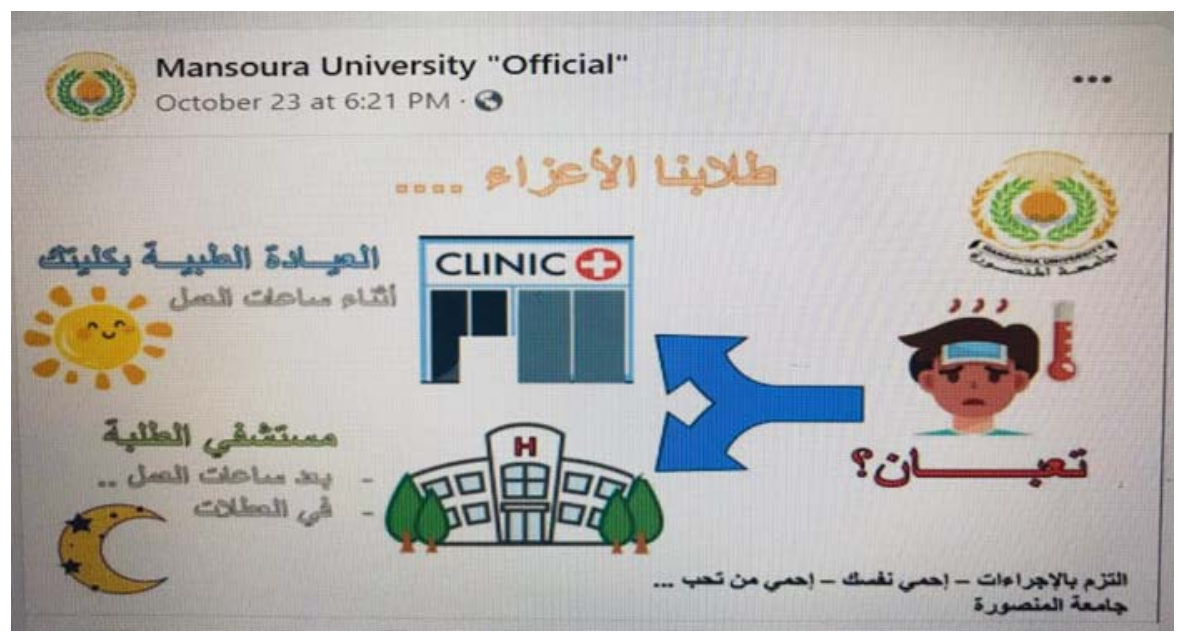


Discourse and Identity in the Digital World: Mansoura University Website as a Model

Dr. Rehab Farouk Gad

\section{مجلة وادي النيل للاراسات والبحوث الإنسانية والاجتماعية والتربوية (مجلة علمية محكمة)}

One limitation of the study is that examples of informal written language displayed on MU website were seldom found (few examples are given in Appendix $b$ followed by proposed translation). This reflects the tendency to promote and preserve Modern Standard Arabic. Again, the above excerpt is highly representative of a friendly message addressed to the undergraduate students on the importance of immediate actions in case of developing any symptoms of Covid-19. Adapting language according to the age and education of the interlocutors is a type of socio-linguistic awareness which digital discourse studies underpin (detailed investigations of the sociolinguistic aspects of digital discourse are proposed by Androutsopoulos 2006, De Fina, Schiffrin \& Bamber 2006 and Blitvich \& Bou-Franch 2019). In the above excerpt, text and picture combine to create an interesting image relevant for its target audience (a detailed analysis of textpicture combinations and how they generate implicated meaning is proposed by Yus 2019). Based on the above excerpt, the following remarks are drawn:

1. The target audience is explicitly mentioned طلابنا "Our Dear Students”. Possession here reflects a sense of intimacy, so the suffix ن "our" is attached to the noun طلاب "students".

2. A yes/no question is formed with an informal (colloquial Egyptian expression) language: تعبان?. “tired?”, instead of the standard متعب "tired” to ensure that the message is understood. In the Egyptian culture, this informal word is normally associated with any degree of diseases.

3. A thermometer is placed next to the student showing signs of Covid-19

4. Covid-19 is not explicitly mentioned though some phrases which are usually repeated in Covid-19 related contexts appeared at the end of the excerpt: التزم

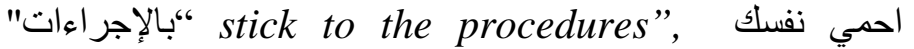
"protect yourself” and احمي من تحب "protect your 
beloved".

5. The picture plays a substantial role in conveying the message with less written text.

\subsubsection{Concluding Remarks}

Goffman (1959) views social identity as a kind of performance. People interact with each other and manage their own information preserves which allow them to say something and hide something else. So, when people choose to uncover some aspects of their personalities, they are actually performing. Identity performance, according to Goffman, needs to be presented by certain equipment. A closer examination of the website under investigation reveals that the equipment used here by $\mathrm{MU}$ as an academic and educational institution, to construct its own social identity is shifting between the three types of digital discourse discussed: each type is adapted to the situation described, and to the type of identity it attempts to promote. In other words, each type of identity induces an alteration in genres and styles. So, I assume here that what we have are three digital discourse types (i.e. informative, persuasive and informal) adapted to promote three identities (i.e. educational, social and international) as illustrated by the following figure:

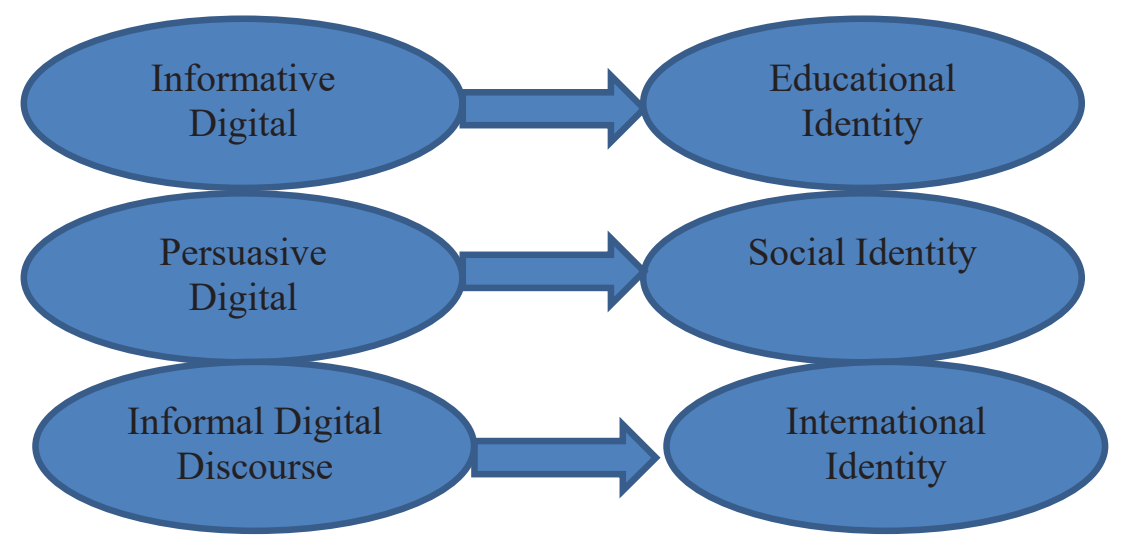

Fig. 1 A digital discourse-based classification of identity 
Discourse and Identity in the Digital World: Mansoura University Website as a Model

Dr. Rehab Farouk Gad

$$
\text { مجلة وادي النيل للاراسات والبحوث الإنسانية والاجتماعية والتربوية (مجلة علمية محكمة) }
$$

Adding a new dimension to the way identity is represented in the digital media, a further assumption is proposed here, following the claim that "by facilitating new modes of productivity, socialization and representation, technology has helped transform the stage on which language and identity is performed" (Darvin, 2016, p. 526). The present study takes the new modes of selfrepresentation, which the written language of the selected excerpts reflects, as actual types of identity listed in figure (2):

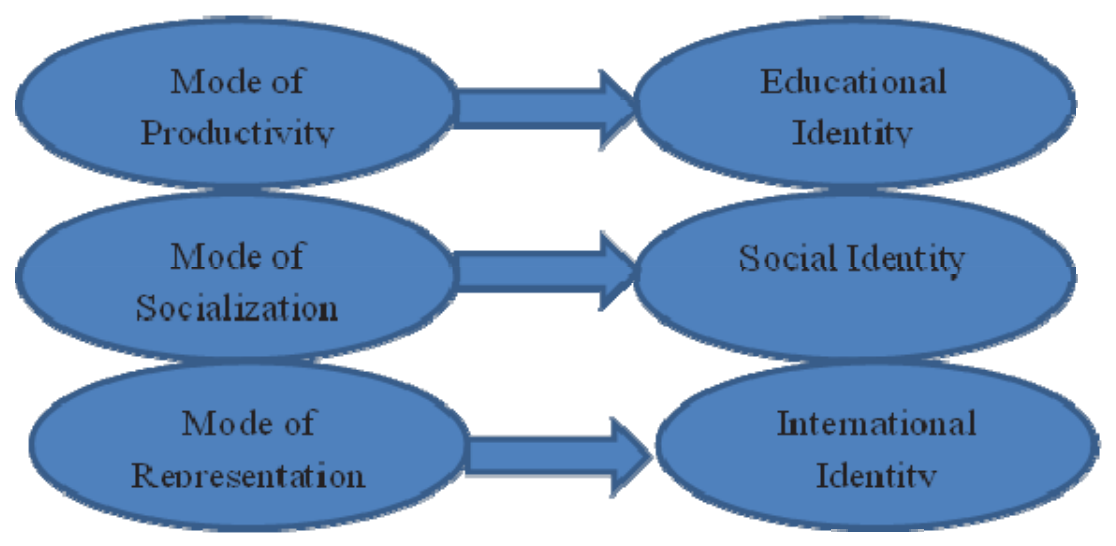

Fig. 2 Modes of self-representation \& identity types

The present study suggests that the information displayed on the target website has transformed MU to a commodity (an academic institution with educational, social and international identities). Instead of concluding that MU is an academic institution with multiple identities, it is plausible to describe it as adopting a Commodified Identity as represented by the following figure: 


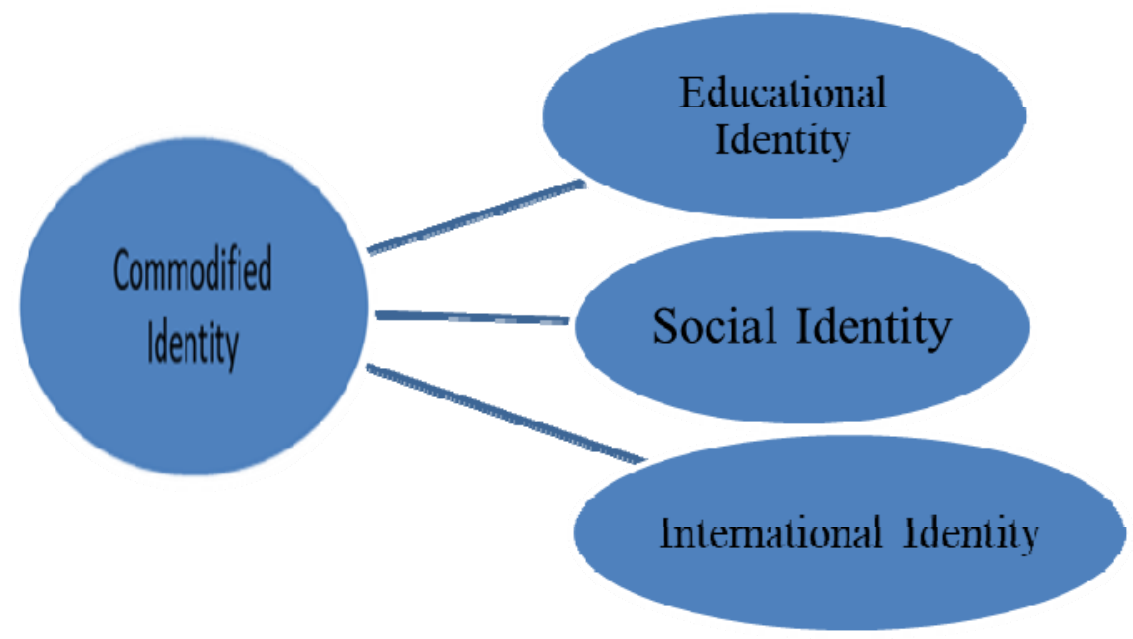

Fig.3 Representation of multiple identities

\section{Discussion of results and concluding remarks}

The present study was motivated by the need to investigate the way ideologies about media can be represented in the digital world. It aimed at investigating how the institutional and academic identity of Mansoura University is represented and performed in the digital world by language-oriented means. Digital technology has made all multimodal resources available to the users of websites to do so many things. The digital language used in MU website reflects ideological and identity positioning of the university. The study concludes that the new type of language displayed on Mansoura University website has successfully contributed to reshape both the academic and social practices of Mansoura University as an institution that is able to identify its own ideologies and underpins its identity. The digital language of titles and texts on the website employs semiotic resources to suggest a complementary perspective that helps evoke a sense of a corporate identity. Images, videos and language work together to create the three corporate identities (educational, social and international) discussed in section 4. 
Discourse and Identity in the Digital World: Mansoura University Website as a Model

Dr. Rehab Farouk Gad

\section{مجلة وادي النيل للاراسات والبحوث الإنسانية والاجتماعية والتربوية (مجلة علمية محكمة)}

In conclusion, contemporary advances in digital world have given rise to distinctive ways of displaying academic and institutional identities. The availability of technology to create an academic institution's professional- quality website has transformed the traditional way of identity construction. MU website is a means of self- presentation that is manipulated for impression management and projection of online identity. Through the website, MU displays academic, social, educational and international position to other Egyptian state universities. MU website is described as a dynamic platform that allows interplay between different aspects of an academic institution's diverse educational, social and international identities. Having said that new practices of using language as a means of identity representation are now offered by the new digital tools available, a comparative study with wider scopes is recommended to investigate how language works in the digital media of other academic platforms to reflect issues of identity.

\section{References}

Androutsopoulos, J. (2006). Introduction: Sociolinguistics and computer-mediated communication. Journal of Sociolinguistics, 10 (4), 419-438.

Blank, G \& Reisdorf, B. (2012). The participatory web: A user perspective on Web 2.0. Information, Communication \& Society, 15(4), 537- 554.

Retrieved from https://doi.org/10.1080/1369118X.2012.665935

Blitvich, P., \& Bou-Franch, P. (2019). Introduction to analyzing digital discurse: New insights and future directions. In P, BouFranch, P, Garces-Corejos Blitvich (Eds.), Analyzing digital discourse: New insights and future directions (pp.3-22). Palgrave: Macmillan. 
(ISSN : 2536 - 9555)

Bou-Franch, P., \& Blitvich, Pilar G. (2019). Analyzing digital discourse: New insights and future directions. Basingstoke: Palgrave Macmillan.

Bourdieu, P., \& Wacquant, L. (1992). An invitation to reflexive sociology.

Chicago:

University of Chicago Press.

Chouliaraki, L., \& Morsing, M. (2009). Media, organization and identity. Basingstoke: Palgrave Macmillan.

Cope, B. \& Kalantzis, M. (2012). Literacies. Cambridge: Cambridge University Press.

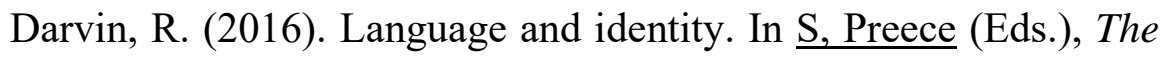
Routledge handbook of language and identity (pp. 523- 540). London \& New York: Routledge Taylor \& Francis Group.

De Fina, A., Schiffrin, D., \& Bamber, M. (Eds.).( 2006 ). Discourse and identity. Cambridge: Cambridge University Press.

Ellison, N.B, Steinfeld, C., \& Lampe, C. (2007). The benefits of Facebook 'friends': Social capital and college students' use of online social network sites. Journal of Computer-Mediated Communication, 13 (1), 210-230.

Fairclough, N. (1992). Discourse and social change. Cambridge, MA: Polity Press.

longman.

(1995). Critical discourse analysis. London:

Gee, J. (2005). An introduction to discourse analysis: Theory and method. London \& New York: Routledge Taylor \& Francis Group 
Discourse and Identity in the Digital World: Mansoura University Website as a Model

Dr. Rehab Farouk Gad مجلة وادي النيل للاراسات والبحوث الإنسانية والاجتماعية والتربوية (مجلة علمية محكمة)

Goffman, E. (1959). The presentation of the self in everyday life. New York: Anchor Books.

Herring, S. C. (1996). Computer-mediated communication: Linguistic, social and cross cultural perspectives. Amsterdam: John Benjamins.

Helliwell, J. F., \& Putnam, R. D. (2004). The social context of well-being. Philosophical Transactions of the Royal Society, 359 (1449), 1435-1446.

Holmes, J. (2006). Workplace narratives, professional identity and relational practice. F, Anna., S, Deborah., \& B, Michael (Eds.), Discourse and identity (pp.166-212). Cambridge: Cambridge University Press.

Horton, K., \& Wanderley, C. (2018). Identity conflict and the paradox of embedded agency in the management accounting profession: Adding a new piece to the theoretical jigsaw. Management Accounting Research, 38, (3), 39-50

Jenkins, H. (2006). Convergence culture: Where old and new media collide. New York: New York University Press.

Jones, R., Chick, A. \& Hafner, C. (2012). Understanding digital literacies: A practical introduction. London: Routledge.

(2015). Discourse and digital practices: Doing discourse analysis in the digital age. London: Routledge.

Kelly, M. (2013). A look back at 20+ years of website design.

Retrieved from https://blog.hubspot.com/marketing/look-back-20years-website-design 
(ISSN : 2536 - 9555)

Labrecque, L. I., Markos, E., \& Milne, G.R. (2011). Online personal branding: Processes, challenges, and implications. Journal of Interactive Marketing 25, 37-50.

Müller, M. (2017). Digital discourse analysis. Retrieved from https://www.digitalhumanitiescooperation.de/en/pamphlete/pamphl et-5-digitale-diskursanalyse/

Norton, B. (2013). Identity and language learning: Extending the conversation. Bristol: Multilingual Matters.

Petroni, S. (2019). How social media shape identities and discourses in professional digital settings: Self-communication or self-branding? In P, Bou-Franch, P, Garces-Corejos Blitvich (Eds.), Analyzing digital discourse: New insights and future directions (pp.251-282). Palgrave: Macmillan.

Rodden, J. (2006). Reputation and its vicissitudes. Society, 43(3): 75-80.

Thurlow, C., \& Mroczek, K. (2011). Digital discourse: Language in the new media. Oxford: Oxford University Press.

Warschauer, M. (2009). Digital literacy studies: Progress and prospects. In M. Baynham, M. Prinsloo (Eds.), The Future of literacy studies (pp.123-140). Palgrave: Macmillan.

Yus, F. (2019). Multimodality in Memes: A Cyberpragmatic Approach. In P, Bou-Franch, P, Garces-Corejos Blitvich (Eds.), Analyzing digital discourse: New insights and future directions (pp.105-131). Palgrave: Macmillan. 
Discourse and Identity in the Digital World: Mansoura University Website as a Model

Dr. Rehab Farouk Gad

مجلة وادي النيل للاراسات والبحوث الإنسانية والاجتماعية والتربوية (مجلة علمية محكمة)

Excerpt (1)

(a)

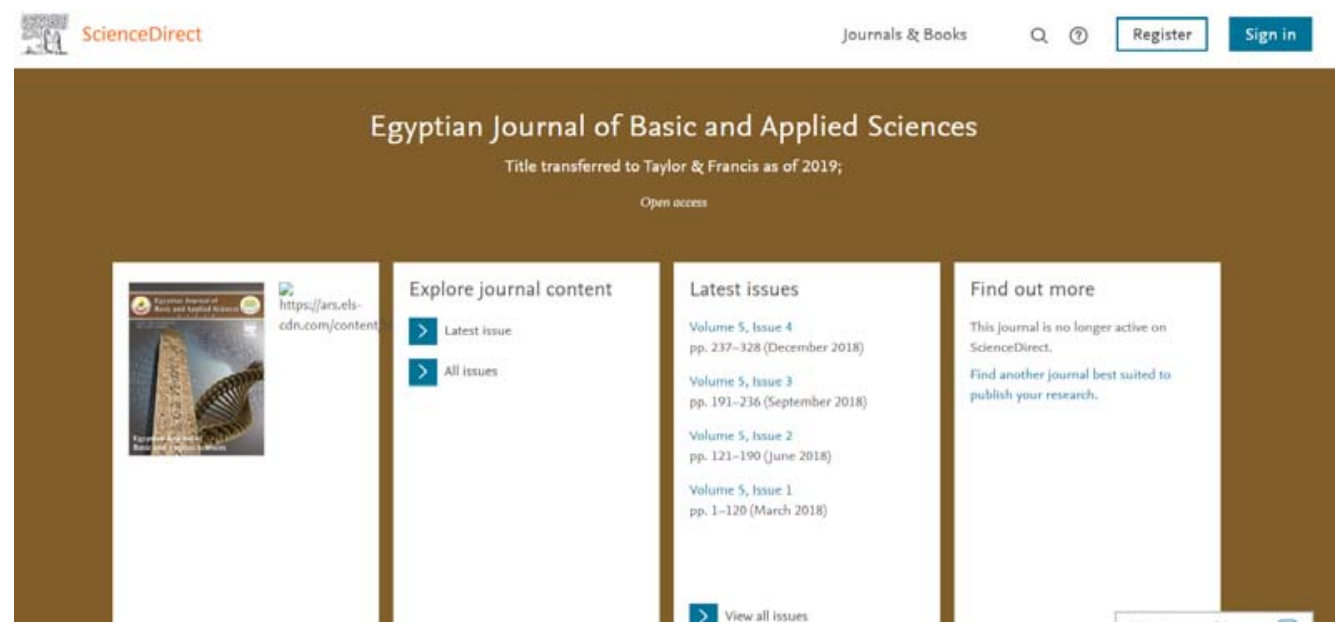

(b)

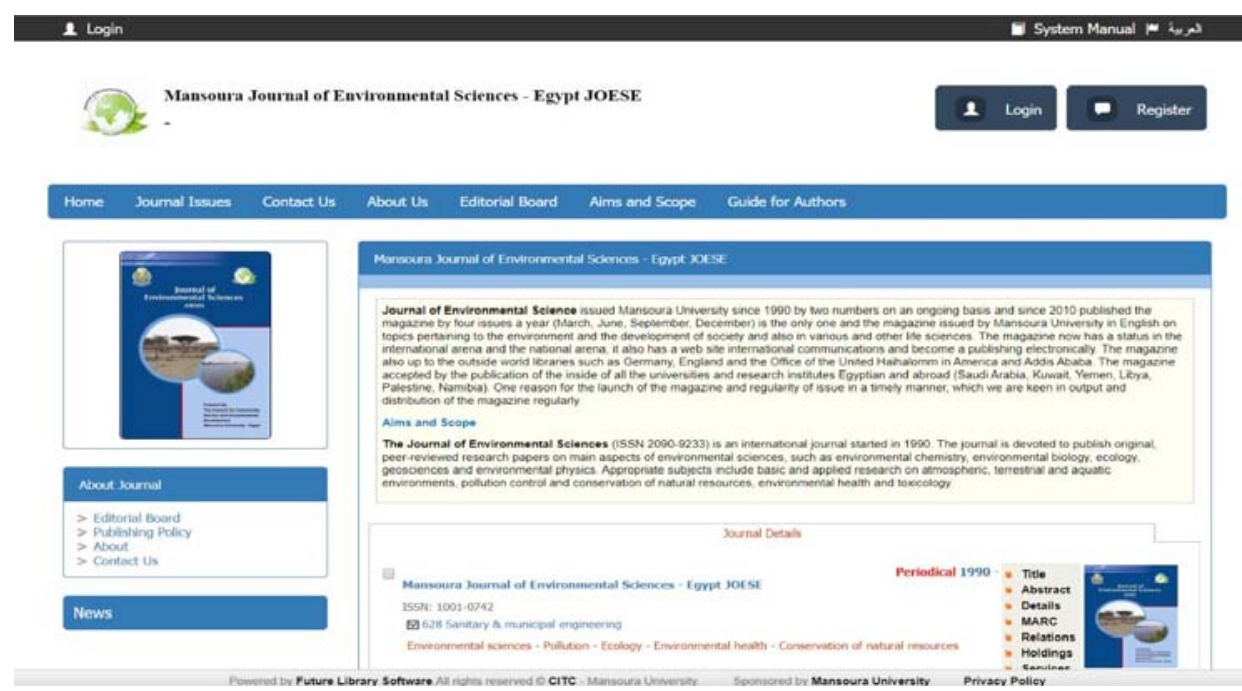


مجلة وادي النيل للاراسات والبحوث الإنسانية والاجتماعية والتربوية (مجلة علمية محكمة)

(ISSN : 2536 - 9555)

\section{Excerpt (2)}

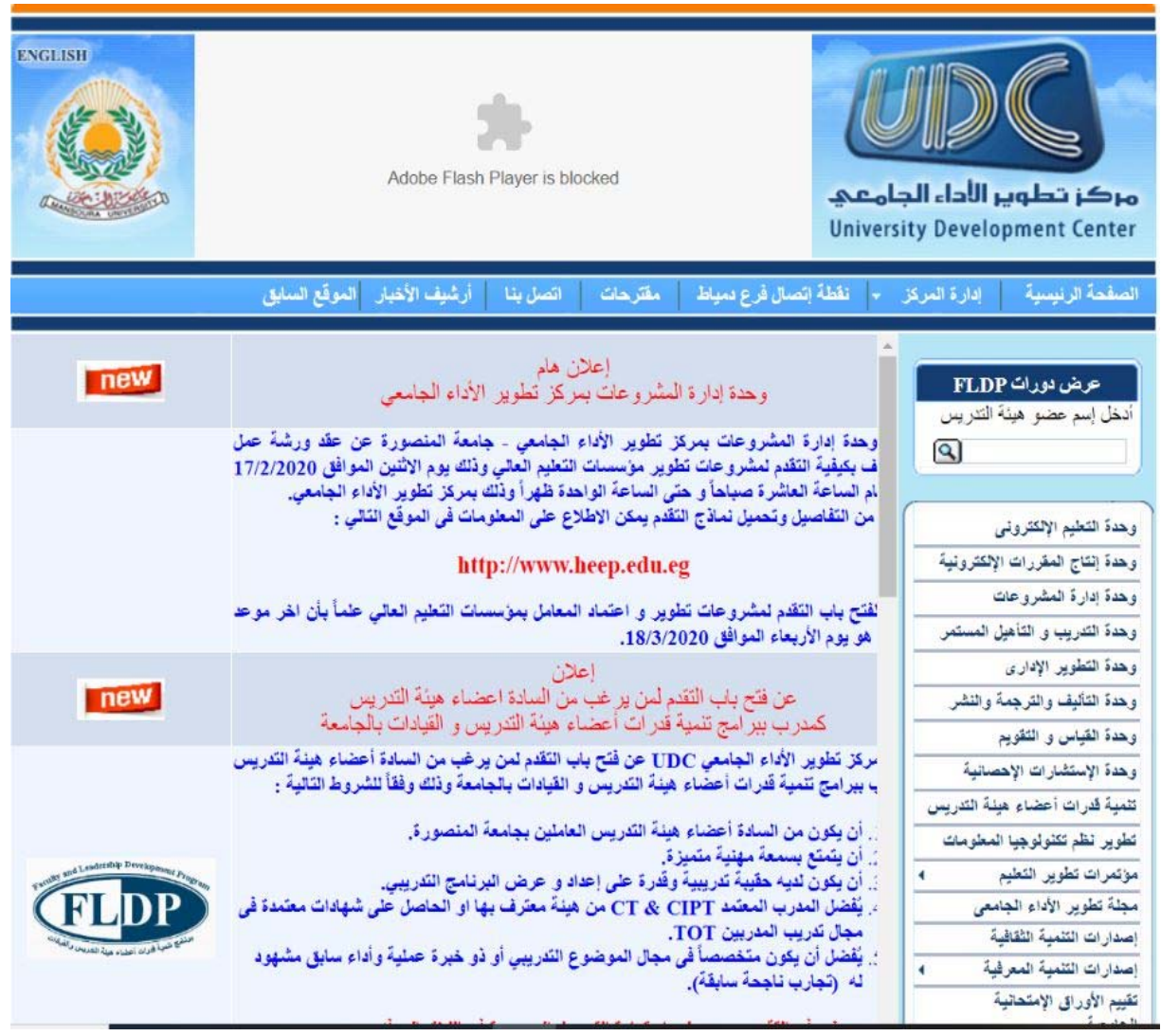




\title{
Discourse and Identity in the Digital World: Mansoura University Website as a Model
}

Dr. Rehab Farouk Gad

\author{
مجلة وادي النيل للاراسات والبحوث الإنسانية والاجتماعية والتربوية (مجلة علمية محكمة)
}

Excerpt (3)

\begin{tabular}{|c|c|}
\hline \multicolumn{2}{|l|}{ 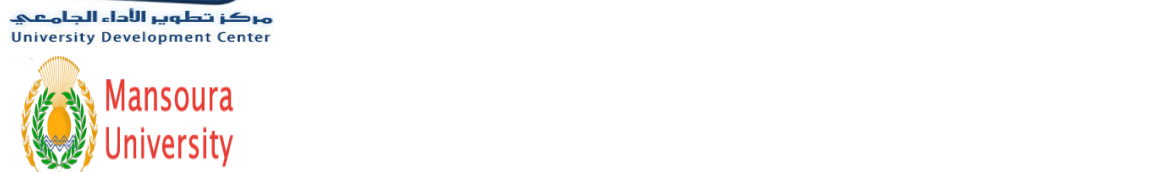 } \\
\hline \multicolumn{2}{|c|}{$\begin{array}{l}\text { home page centre management contact Damietta branch suggestions contac us } \\
\text { news archive former site }\end{array}$} \\
\hline $\begin{array}{l}\text { Display FLDP Courses } \\
\text { Type staff member name } \\
\text { here }\end{array}$ & \multirow{15}{*}{$\begin{array}{l}\text { Important Announcement } \\
\text { Projects Management Unit at University Development } \\
\text { Center } \\
\text { The Projects Management Unit at University } \\
\text { Development Center is organizing a workshop on how } \\
\text { to participate the projects of higher education } \\
\text { institutions development. The workshop is held on } \\
\text { Monday, the } 17^{\text {th }} \text { of February } 2020 \text { (10am - 1pm) at the } \\
\text { University Development Center ....for more details \& } \\
\text { applications, please visit the website below: } \\
\text { Applications for participation in laboratories } \\
\text { development and accreditation are now available and } \\
\text { the deadline is Wednesday, the } 18^{\text {th }} \text { of March } 2020 \text {. } \\
\text { Applications are now available for staff members } \\
\text { wishing to get FLDP training positions who meet the } \\
\text { following requirements: } \\
\text { To be one of the working staff member at Mansoura } \\
\text { University } \\
\text { To have a very distinguished professional reputation } \\
\text { To have experienced training agenda and the ability to } \\
\text { prepare and present the training program. } \\
\text { To be an accredited CIPT \& CT trainer with certified } \\
\text { qualifications in TOT } \\
\text { To have sufficient experience and knowledge on the } \\
\text { topic of his training program; successful training } \\
\text { history is also preferable. }\end{array}$} \\
\hline E-learning unit & \\
\hline E-courses unit & \\
\hline Project Management Unit & \\
\hline $\begin{array}{l}\text { Continuous Training \& } \\
\text { Education Unit }\end{array}$ & \\
\hline $\begin{array}{l}\text { Administration Development } \\
\text { Unit }\end{array}$ & \\
\hline $\begin{array}{l}\text { Writing, Translation \& } \\
\text { Publication Unit }\end{array}$ & \\
\hline $\begin{array}{l}\text { Measurement \& Evaluation } \\
\text { Unit }\end{array}$ & \\
\hline Statistical Consultations Unit & \\
\hline $\begin{array}{l}\text { Staff Members Capabilities } \\
\text { Development }\end{array}$ & \\
\hline $\begin{array}{l}\text { Information Technology } \\
\text { Systems Development }\end{array}$ & \\
\hline $\begin{array}{l}\text { Education Development } \\
\text { Conferences }\end{array}$ & \\
\hline $\begin{array}{l}\text { Journal of University } \\
\text { Performance Development }\end{array}$ & \\
\hline $\begin{array}{l}\text { Culture Development } \\
\text { Publications }\end{array}$ & \\
\hline $\begin{array}{l}\text { Cognitive Development } \\
\text { Publications }\end{array}$ & \\
\hline Exam paper evaluation & \\
\hline
\end{tabular}


مجلة وادي النيل للاراسات والبحوث الإنسانية والاجتماعية والتربوية (مجلة علمية محكمة)

(ISSN : 2536 - 9555)

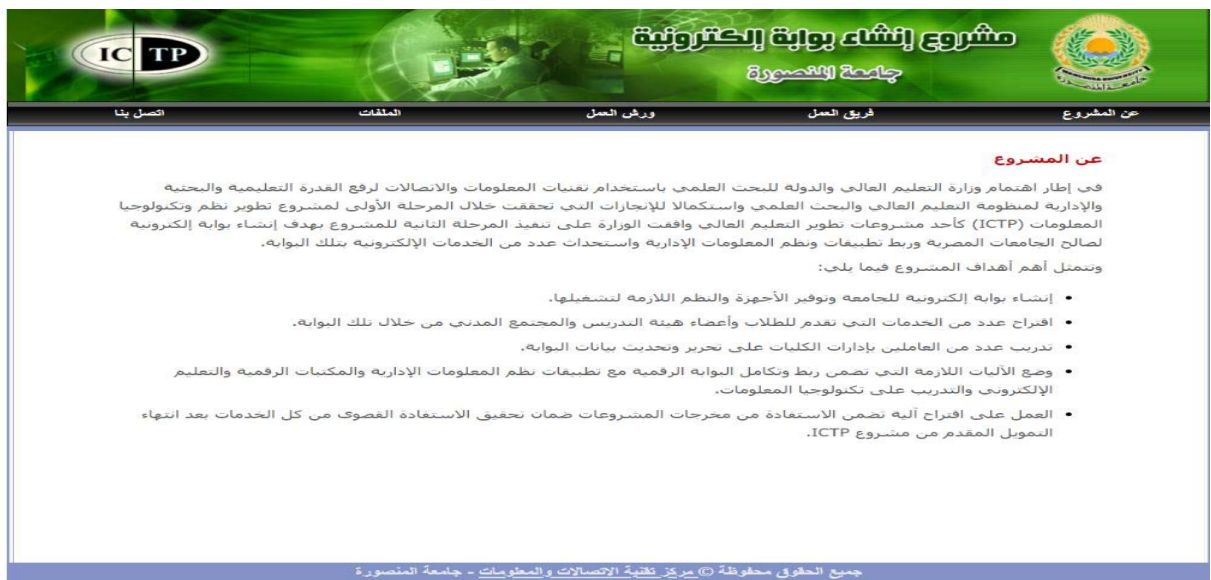

Online Portal Implementation Project
Mc
Project
Us Teansoura University
About the project
The Ministry of Higher Education approved the second phase of the project as part of its concern
with scientific research by means of information and communication technology that boosts
education, research and administration capabilities of higher education and scientific research.
The second phase is a continuity what was achieved from the first phase ICTP as one of the
higher education development projects.
The project's aims are:
implementing an online portal for the university with the necessary operating
equipment and systems
offering services to students, staff members and the community through this
portal
offering a number of employees adequate training on editing and updating the
portal information
setting up mechanisms to ensure linking \&integrating the digital portal with
applications of management information systems, digital library, e-learning
and offering adequate training on information technology
setting up mechanisms to ensure benefiting from project and all services
outputs by the end of ICTP fund




\section{Discourse and Identity in the Digital World: Mansoura University Website as a Model}

Dr. Rehab Farouk Gad

مجلة وادي النيل للاراسات والبحوث الإنسانية والاجتماعية والتربوية (مجلة علمية محكمة)

Excerpt (4)
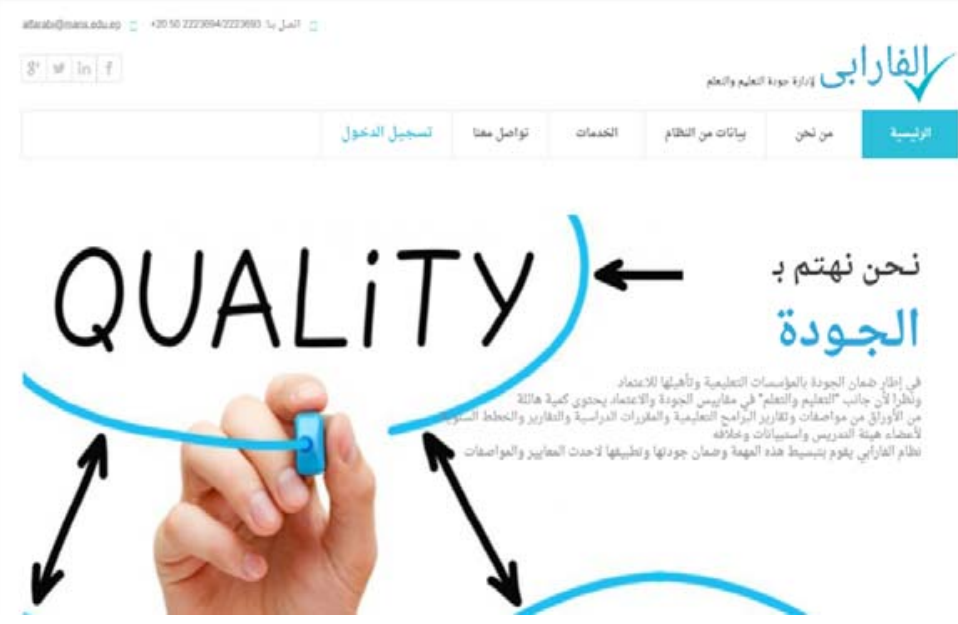

Al- Farabi

Teaching \& Learning Quality Administration

contact us: alfarabe@mans.edu.eg

Tel : +20502223694-2223693

\begin{tabular}{|l|l|l|l|l|l|l|}
\hline & Log in & Contact us & Services & System data & About us & Home \\
\hline
\end{tabular}

We Care about Quality

To ensure QUALITY of the educational institutions and a subsequent accreditation, part of teaching and learning should encompass a bulk of documents on specifications, courses reports, staff members' annual plans, statistics ........etc.

Al-Farabi system makes the mission easy, ensures its quality and handles this task in accordance with the up-to-date standards and specifications. 
(ISSN : 2536 - 9555)

\section{Excerpt (5)}

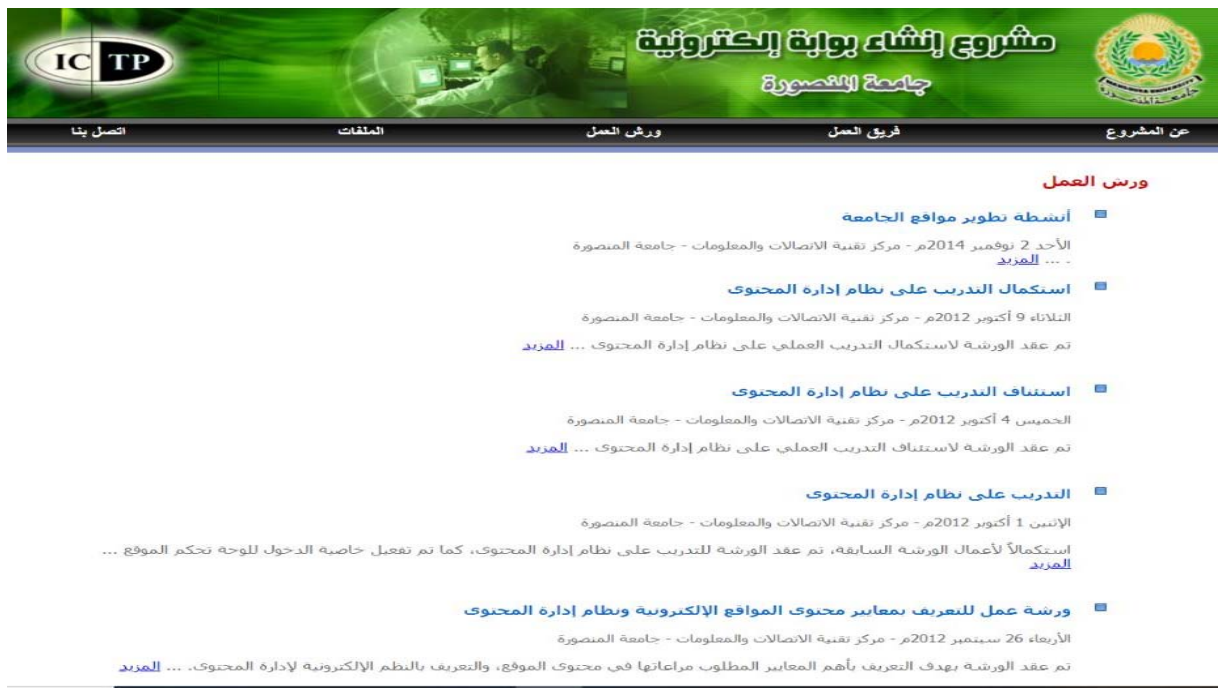

\section{ICTP}

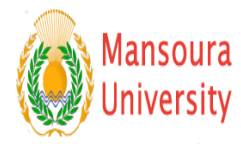

Online Portal Implementation Project

\section{Contact us}

project

Mansoura University

\section{Workshops}

University Websites Development Activities

Sunday 2nd of November 2014- Centre of Communication \& Information Technology- Mansoura University

Read .

$$
\text { ..........more........ }
$$

Content Management System Training Continued

Tuesday 9th of October 2012 - Centre of Communication and Information Technology - Mansoura University

A workshop on commencing content management system training was held ......

Read.

Content Management System Training Resumed

Monday 1 st of October 2012- Centre of Communication \& Information Technology - Mansoura University

A Content Management Training Session, based on previous workshop, was held and access to control panel is now activated

Read.

\section{Workshop on Criteria of Designing Websites Contents and How to Manage Them}

Wednesday $26^{\text {th }}$ of September2012- Centre of Communication \&Information Technology- Mansoura University

The workshop was held to introduce the important required criteria for websites contents and E-Systems of content management

Read .... more. 


\title{
Discourse and Identity in the Digital World: Mansoura University Website as a Model
}

Dr. Rehab Farouk Gad

\author{
مجلة وادي النيل للاراسات والبحوث الإنسانية والاجتماعية والتربوية (مجلة علمية محكمة)
}

\section{Excerpt (6)}
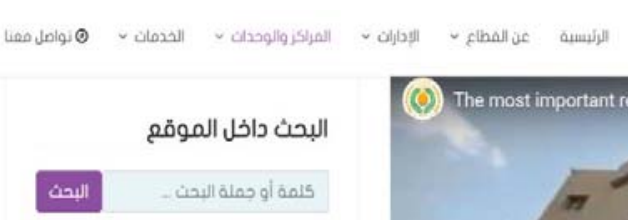

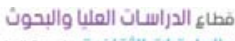

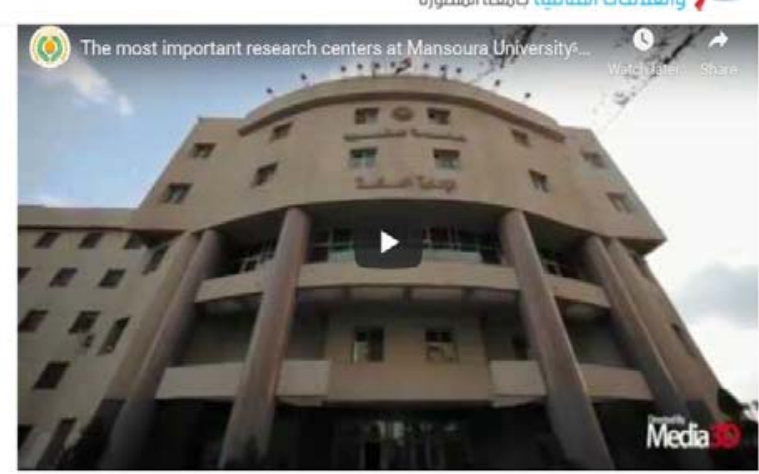

المراكز البحثية ووحدة المعامل

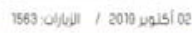

وحدة الميكروسكوب الإلكتروني

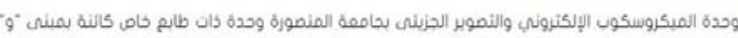

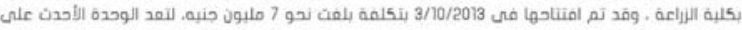

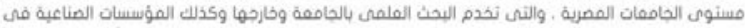

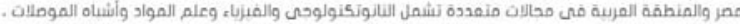

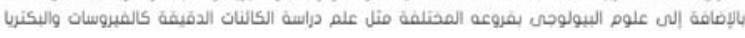

Graduate \&Research Sector and Cultural Affairs
Mansoura University
Administrations Centres \& Units
Contact us
Search the page Search
Research Centres \& laboratories Unit
2 October2019/1563 visits
Electron Microscope Unit
Electron Microscope and Micro-photography Unit at Mansoura University is a special unit
located at building (9) at the faculty of Agriculture. It was opened in 3/10/2013 with a total cost
of 7 million Egyptian pounds, to be the most advanced among the Egyptian universities. The unit
serves the scientific research in and out Mansoura University. It also serves the industrial
establishments in Egypt and Arab region within various areas including Nanotechnology,
Physics, Materials science and Semiconductors, in addition to Biology with its different
branches, such as Microscopy like Viruses and Bacteria.


مجلة وادي النيل للاراسات والبحوث الإنسانية والاجتماعية والتربوية (مجلة علمية محكمة)

(ISSN : 2536 - 9555)

Excerpt (7)

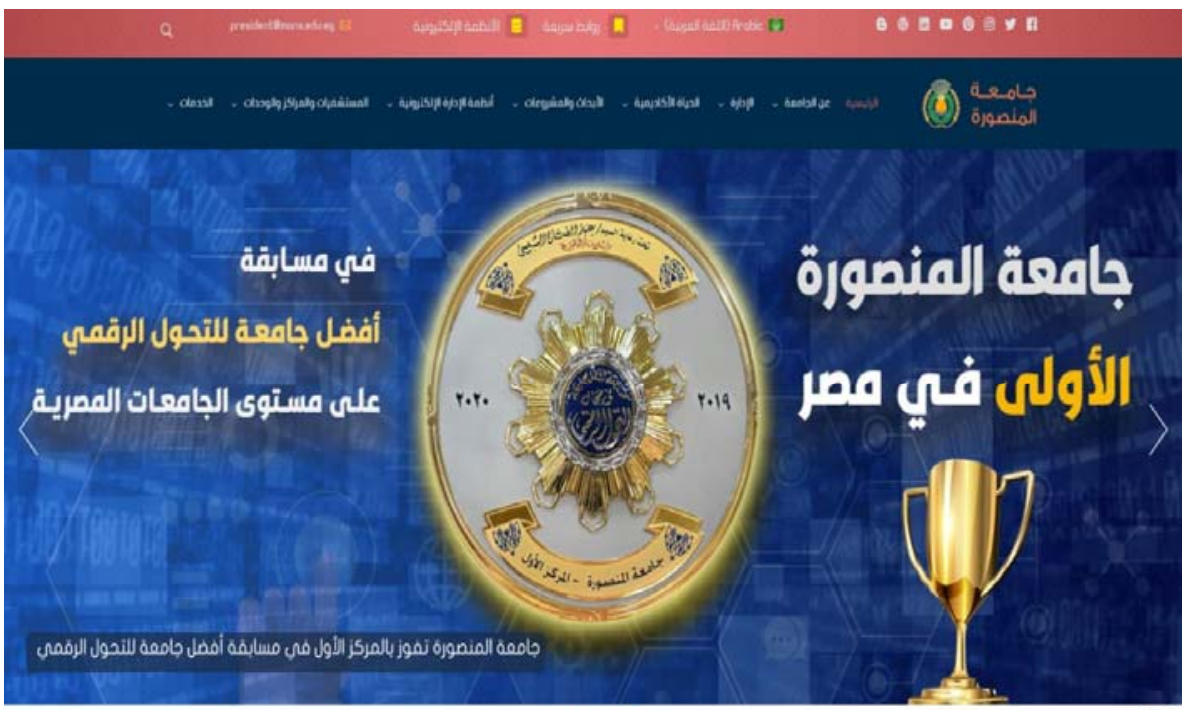

0000000

Arabic (Arabic Language)

Quick links

E-Systems

president@mans.edu.eg

Mansoura University

home page Administration Academic life Researches \&projects E- administration systems

hospitals , units \& centers Services

\section{Mansoura University}

The $1^{\text {st }}$ in Egypt in the competition of digital transformation among Egyptian Universities

Mansoura University wins the first position in universities competition for digital transformation 
Discourse and Identity in the Digital World: Mansoura University Website as a Model

Dr. Rehab Farouk Gad

\section{مجلة وادي النيل للاراسات والبحوث الإنسانية والاجتماعية والتربوية (مجلة علمية محكمة)}

Excerpt (8)

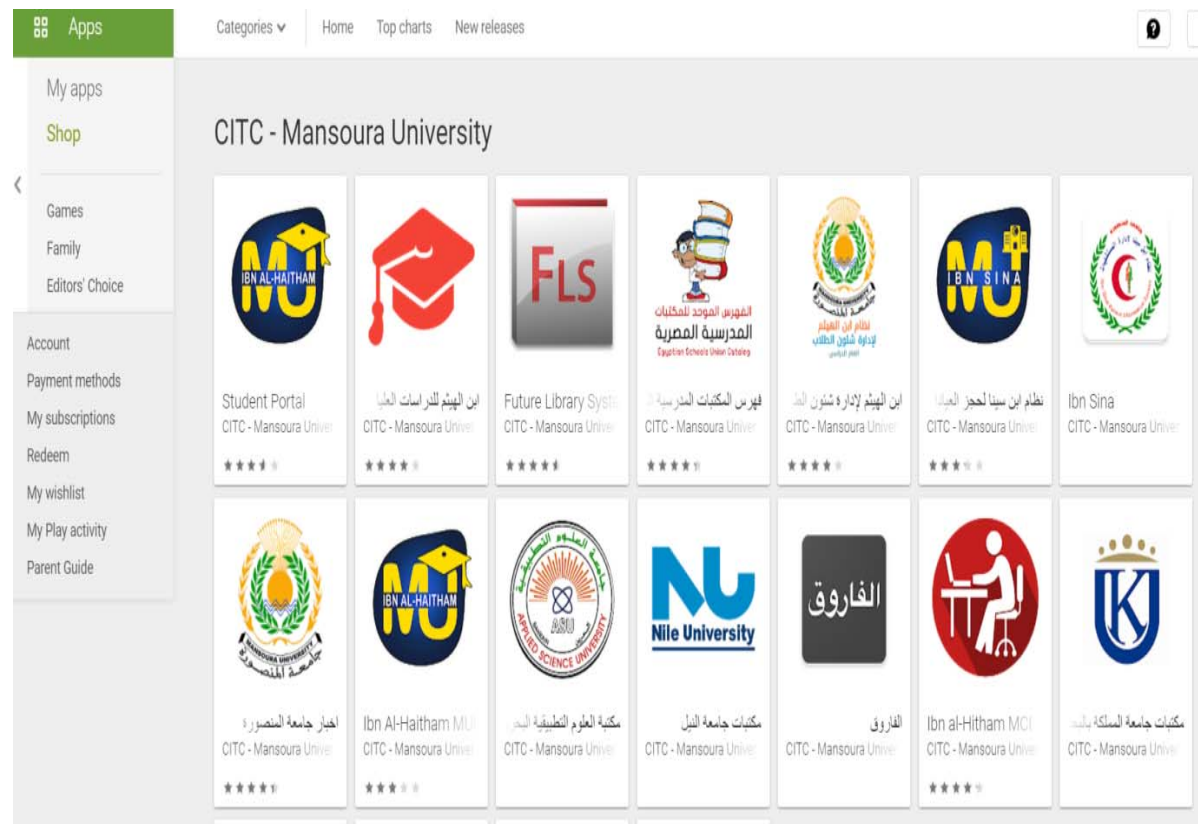

\begin{tabular}{|c|c|c|c|c|c|c|}
\hline \multicolumn{7}{|c|}{ CITI- Mansoura University } \\
\hline $\begin{array}{l}\text { Student } \\
\text { Portal } \\
\text { CITC- } \\
\text { Mansoura } \\
\text { University }\end{array}$ & $\begin{array}{l}\text { Ibn al- } \\
\text { Hitham For } \\
\text { higher } \\
\text { studies } \\
\text { CITC- } \\
\text { Mansoura } \\
\text { University }\end{array}$ & $\begin{array}{l}\text { Future } \\
\text { Library } \\
\text { System } \\
\text { CITC- } \\
\text { Mansoura } \\
\text { University }\end{array}$ & $\begin{array}{l}\text { Egyptian } \\
\text { schools } \\
\text { union } \\
\text { catalog } \\
\text { CITC- } \\
\text { Mansoura } \\
\text { University }\end{array}$ & $\begin{array}{l}\text { Ibn al- } \\
\text { Hitham For } \\
\text { students } \\
\text { affairs } \\
\text { CITC- } \\
\text { Mansoura } \\
\text { University }\end{array}$ & $\begin{array}{l}\text { Ibn Sina For } \\
\text { clinic } \\
\text { appointments } \\
\text { CITC- } \\
\text { Mansoura } \\
\text { University }\end{array}$ & $\begin{array}{l}\text { Ibn Sina For } \\
\text { hospitals } \\
\text { management } \\
\text { CITC- } \\
\text { Mansoura } \\
\text { University }\end{array}$ \\
\hline $\begin{array}{l}\text { Mansoura } \\
\text { University } \\
\text { News } \\
\text { CITC- } \\
\text { Mansoura } \\
\text { University }\end{array}$ & $\begin{array}{l}\text { Ibn al- } \\
\text { Hitham } \\
\text { MU } \\
\text { CITC- } \\
\text { Mansoura } \\
\text { University }\end{array}$ & $\begin{array}{l}\text { Marine } \\
\text { applied } \\
\text { science } \\
\text { library } \\
\text { CITC- } \\
\text { Mansoura } \\
\text { University }\end{array}$ & $\begin{array}{l}\text { Nile } \\
\text { University } \\
\text { Libraries } \\
\text { CITC- } \\
\text { Mansoura } \\
\text { University }\end{array}$ & $\begin{array}{l}\text { Al-Farouq } \\
\text { CITC- } \\
\text { Mansoura } \\
\text { University }\end{array}$ & $\begin{array}{l}\text { Ibn al-Hitham } \\
\text { MCI } \\
\text { CITC- } \\
\text { Mansoura } \\
\text { University }\end{array}$ & $\begin{array}{l}\text { United } \\
\text { Kingdom } \\
\text { Libraries } \\
\text { CITC- } \\
\text { Mansoura } \\
\text { University }\end{array}$ \\
\hline
\end{tabular}


مجلة وادي النيل للار اسات والبحوث الإنسانية والاجتماعية والتربوية (مجلة علمية محكمة)

(ISSN : 2536 - 9555)

Excerpt (9)

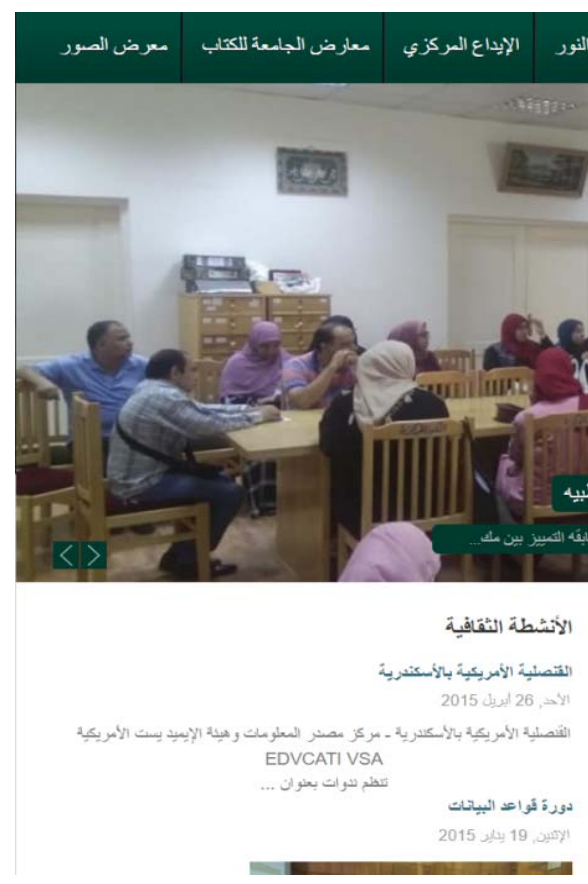

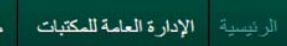
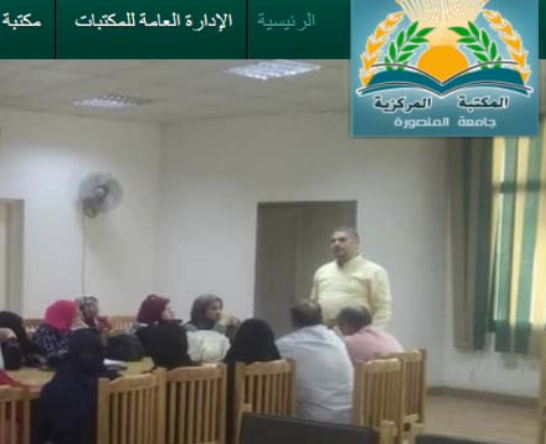

مسابقه التمييز بين مكثبات الكليات والمكتبه المركزيه ومكتبات المراكز الطبيه

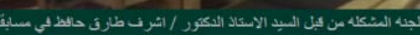

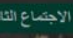

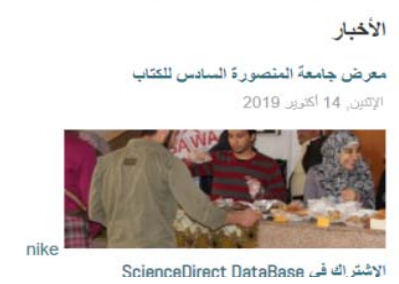

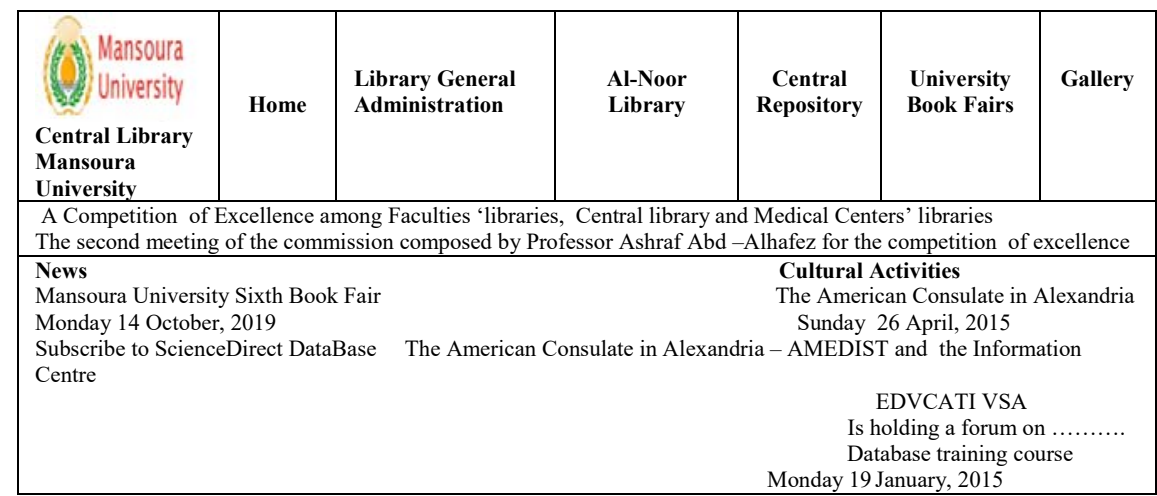




\title{
Discourse and Identity in the Digital World: Mansoura University Website as a Model
}

Dr. Rehab Farouk Gad

\author{
مجلة وادي النيل للاراسات والبحوث الإنسانية والاجتماعية والتربوية (مجلة علمية محكمة)
}

Excerpt (10)

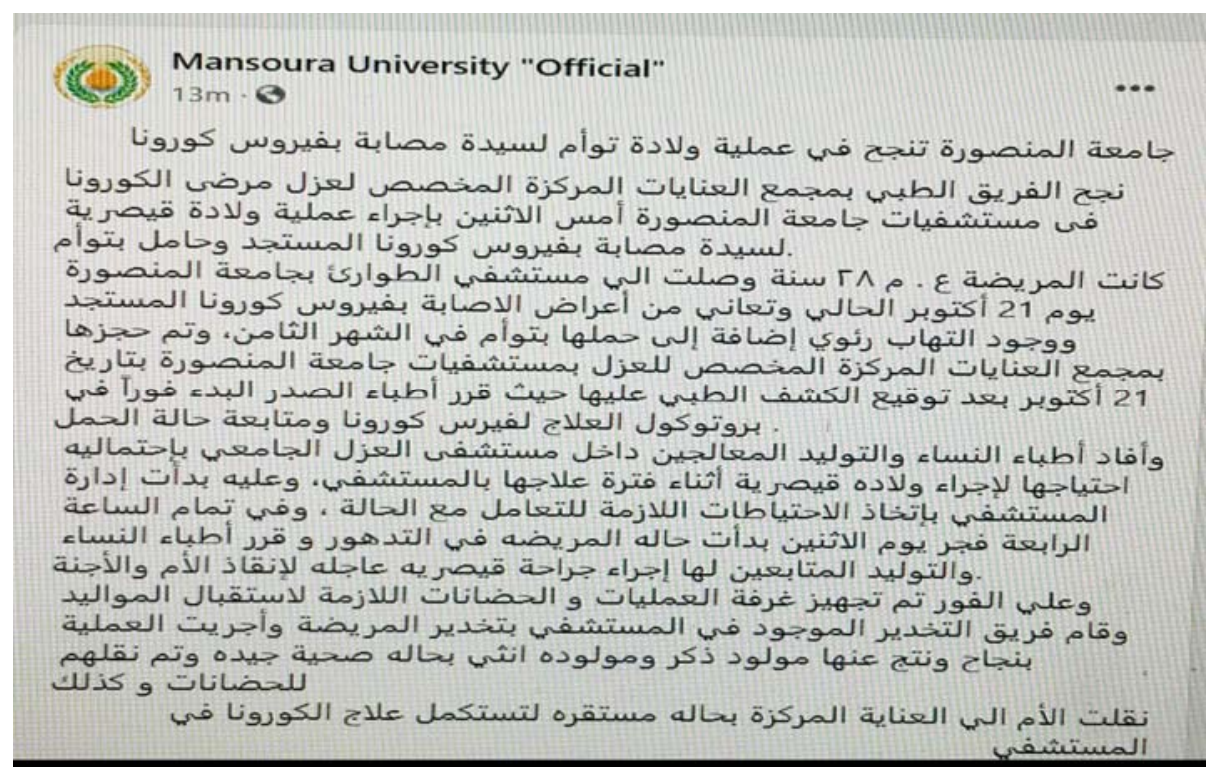

\section{Mansoura University "Official"

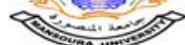 \\ viansoura university succeeded in twin delivery operation of a Covid -19 female patient}

The medical team of the intensive care complex for Corona Virus patients' isolation succeeded in cesarean operation of a Covid -19 female patient last Monday. The patient arrived at the Emergency hospital on the $21^{\text {st }}$ of October with symptoms of Corona Virus and Pneumonia while being eight months pregnant. After medical examination, pulmonologists decided to apply Corona Virus protocol and pregnancy monitoring was carried out. Gynecologists advised that a cesarean operation might be executed while medical care at the isolation hospital is given with taking all the precautions required. At 4 am on Monday, patent's medical conditions deteriorated, so doctors decided for an emergency cesarean to save mother and babies. Operation theatre and neonatal nurseries got ready immediately to receive the babies. The hospital's anesthesiology team worked on the case, the operation was done successfully. Male and female babies were delivered in good health and moved to neonatal nursery unit, and the mother shifted to the ICU in a stable condition to resume Corona Virus treatment at the hospital. 
Excerpt (11)
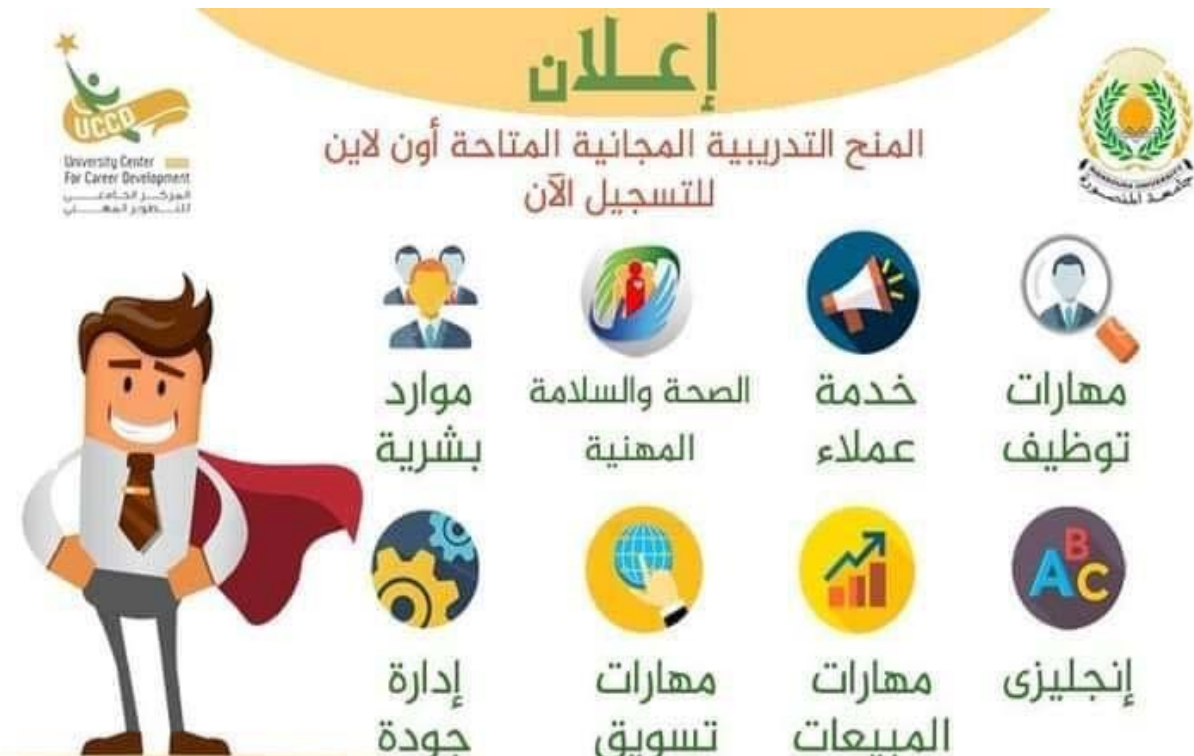

موارد

الصحة والسلامة

خدمة

مهارات

بشرية

المهنية

عملاء

توظيف
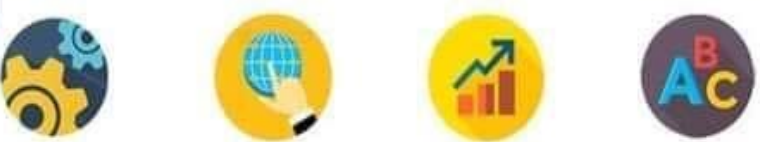

إدارة

همارات

مهارات

إنجليزى

جودة

تسويق

المبيعات

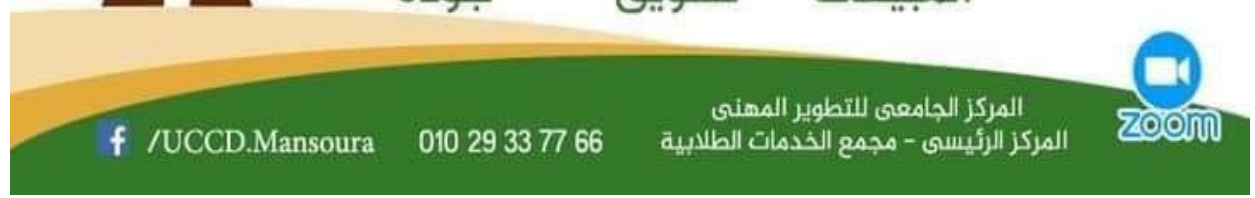

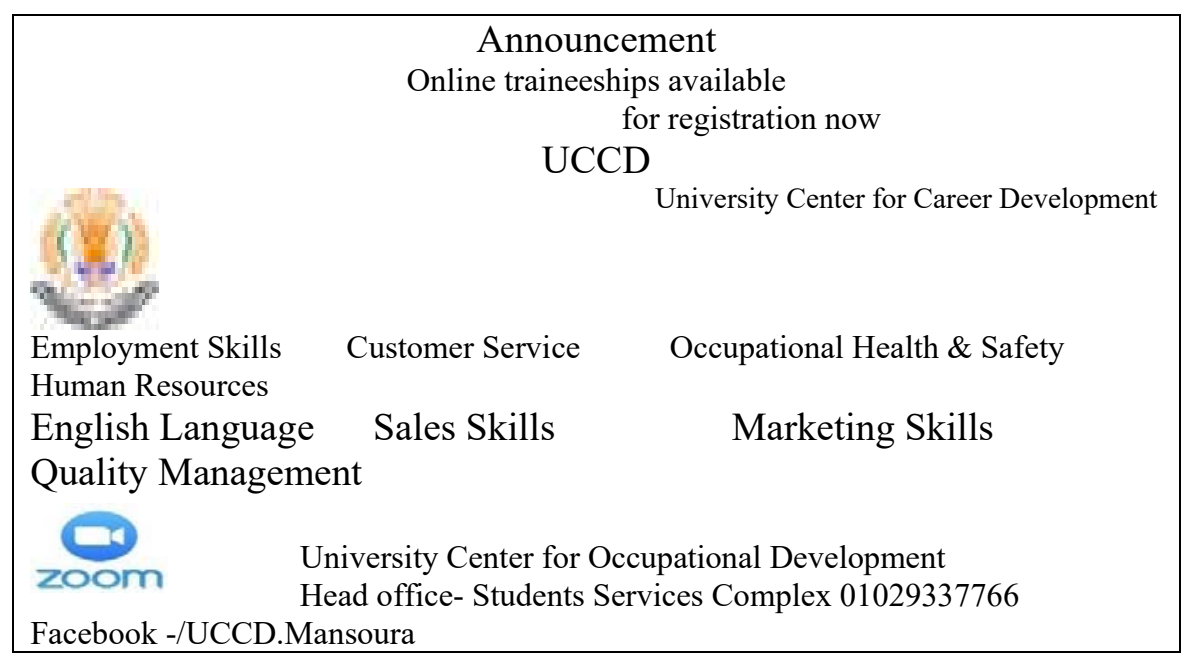

$(800)$ 
Discourse and Identity in the Digital World: Mansoura University Website as a Model

Dr. Rehab Farouk Gad

مجلة وادي النيل للاراسات والبحوث الإنسانية والاجتماعية والتربوية (مجلة علمية محكمة)

Excerpt (12)

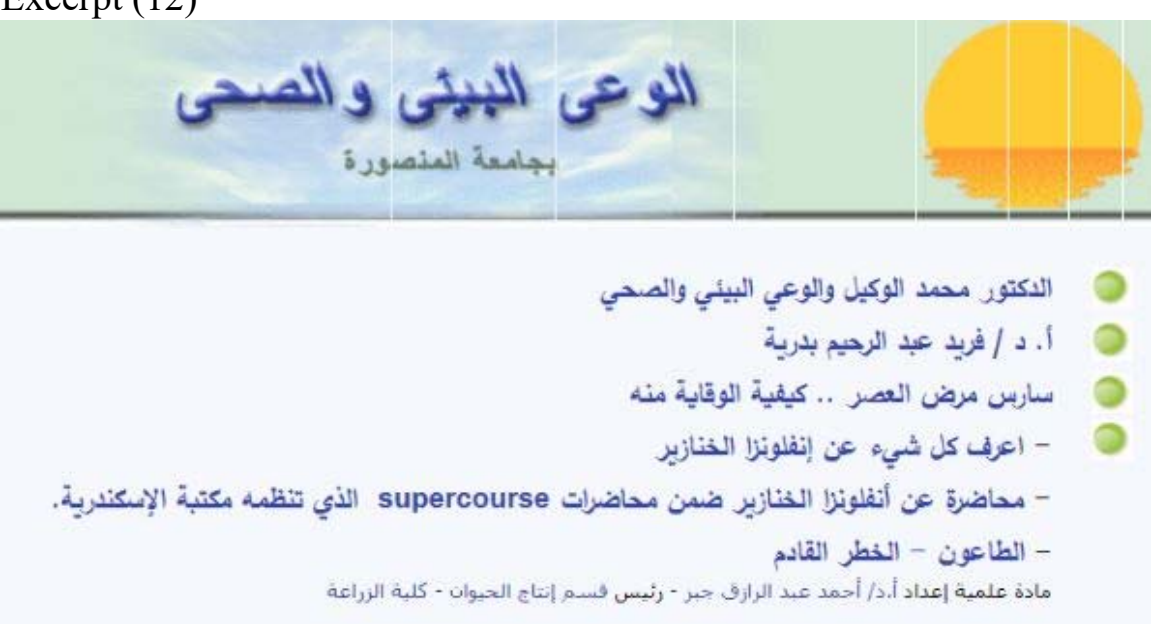

مادة علمية اعداد أ.د/ أحمد عبد الرازف جبر - رئيس قسم إنتاج الحيوان - كلية الزراعة

\section{Environmental \& Health Awareness \\ Mansoura University}

- Prof.Mohamed Al-Wakeeel and Environmental \& Health Awareness

- Prof. Farid Abdul-Raheem Badreya

- SARS, the scourge of the age, ..... how to prevent it

- know everything about swine flu

- A lecture about swine flu, one of the supercourse lectures organized by Alexandria Library

- Plague, the upcoming threat

Resource material prepared by Prof. Ahmed abdul Razeq Gabr: Head of the Department of Animal - Faculty of Agriculture 
مجلة وادي النيل للاراسات والبحوث الإنسانية والاجتماعية والتربوية (مجلة علمية محكمة)

(ISSN : 2536 - 9555)

Excerpt (13)

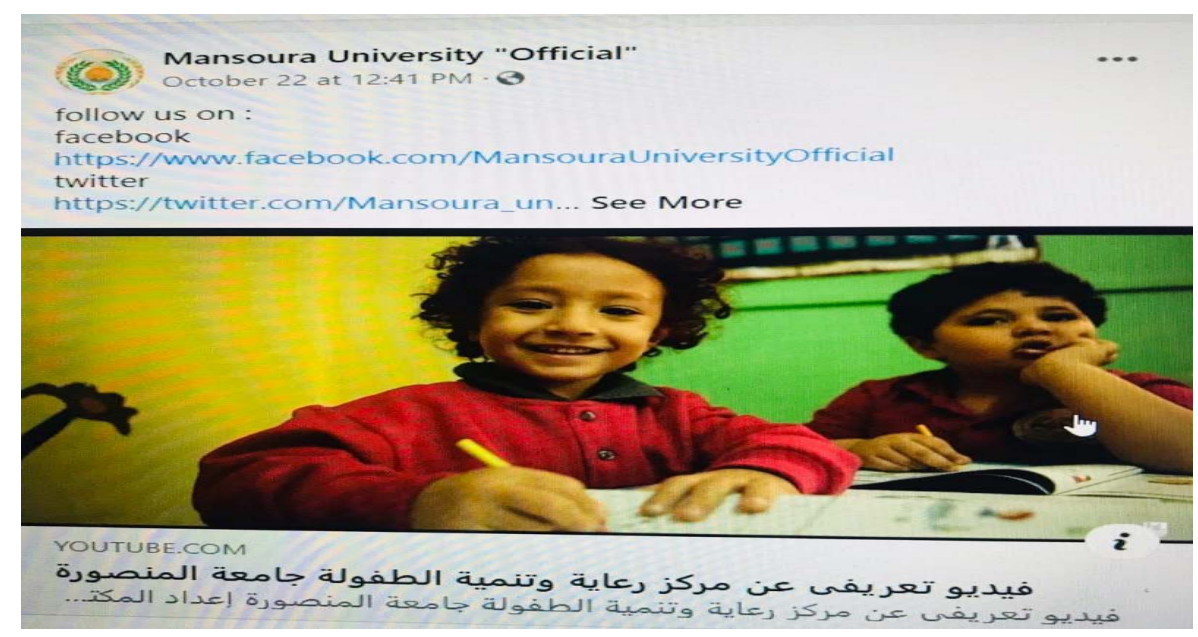

Mansoura University "Official"

October 22 at 12:41PM

Follows us on :

facbook

https://www.facbook.com/MansouraUnversityOffical twitter

http:/twitter.com/Mansoura_un ....... See More

Presentational Video on Child Welfare \& Development Centre - Mansoura University 
Discourse and Identity in the Digital World: Mansoura University Website as a Model

Dr. Rehab Farouk Gad

مجلة وادي النيل للاراسات والبحوث الإنسانية والاجتماعية والتربوية (مجلة علمية محكمة)

Excerpt (14)

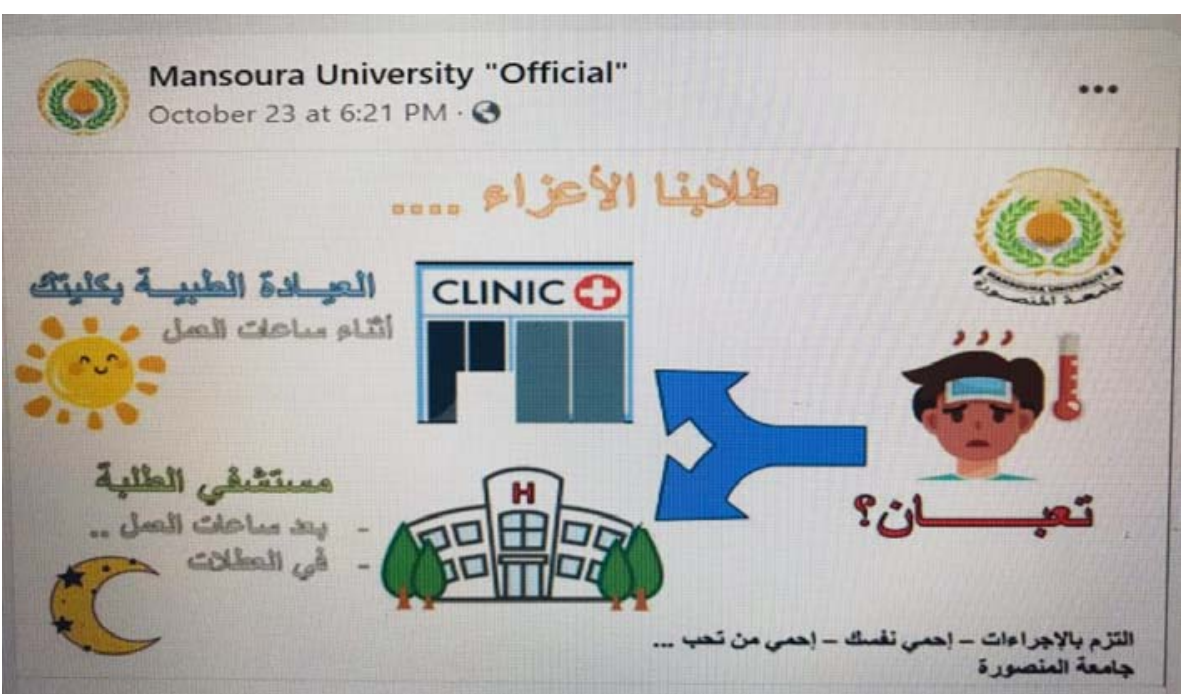

\begin{tabular}{|lcc|}
\hline \multicolumn{1}{|c|}{ Mansoura } & University \\
\hline $\begin{array}{l}\text { Feeling sick } \\
\text { Clinic at your faculty }\end{array}$ & Dear Students ........ \\
working hours & Medical \\
Feeling sick & during \\
Hospital & Students \\
working hours \&holidays & off \\
Stick to the procedures- protect yourself- protect your beloved............... \\
Mansoura University
\end{tabular}


Excerpt (15)
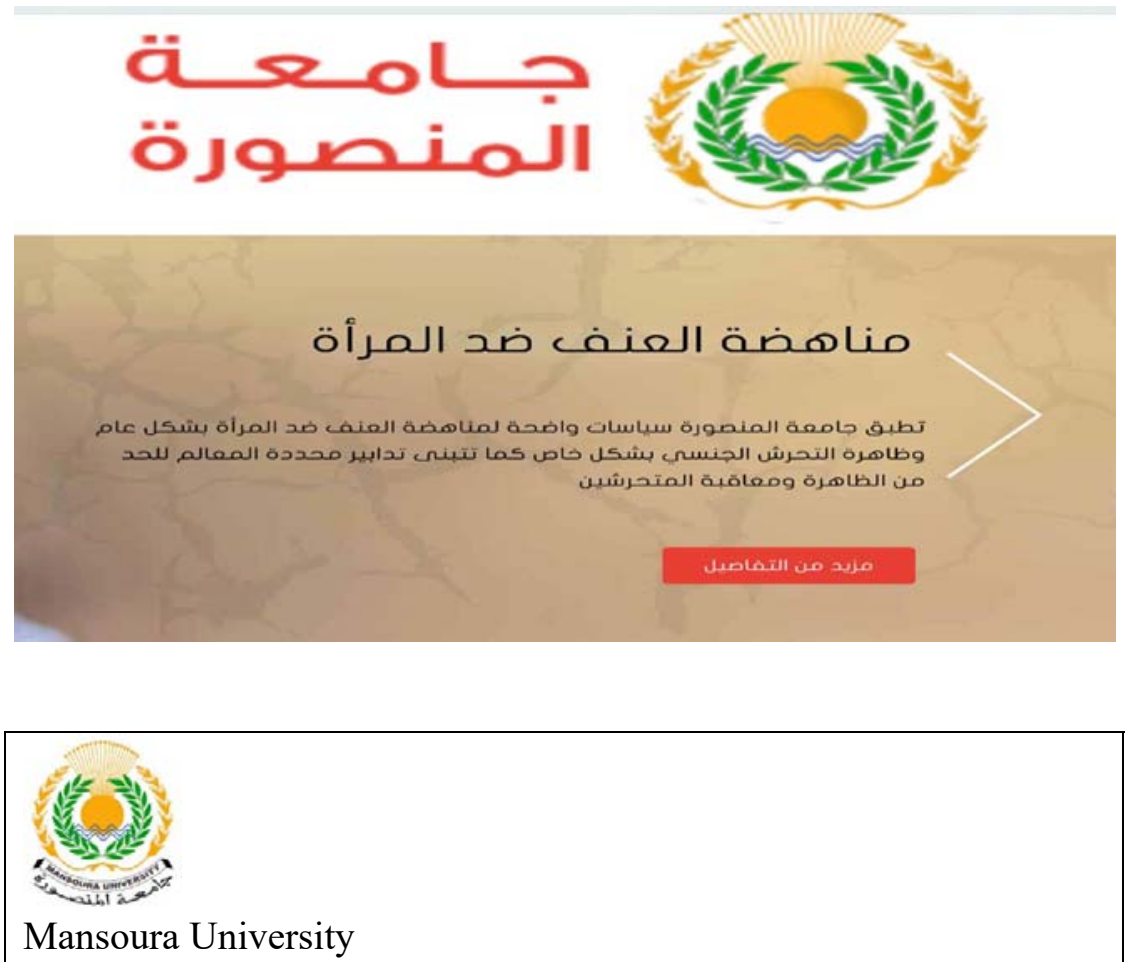

Combat Violence Against Women

Mansoura University is applying clear policies to combat violence, in general, and sexual harassment, in particular, against women. Mansoura University is also adopting decisive measures to alleviate the phenomenon and punish the harassers.

read more........... 
Discourse and Identity in the Digital World: Mansoura University Website as a Model

Dr. Rehab Farouk Gad

مجلة وادي النيل للاراسات والبحوث الإنسانية والاجتماعية والتربوية (مجلة علمية محكمة)

Excerpt (16)

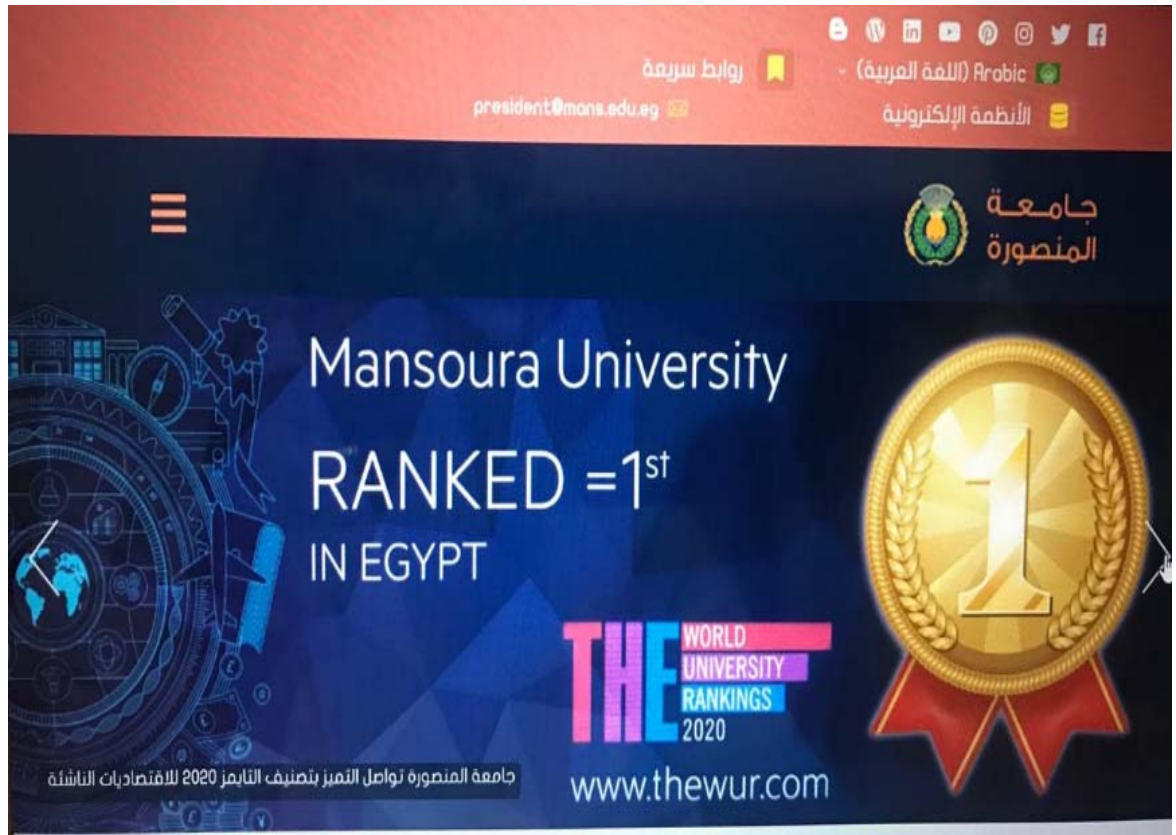

Mansoura

University

\section{Mansoura University}

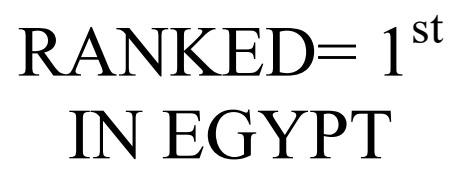

The world University Ranking 2020 www.thewur.com

Mansoura University pursues excellence by the Times2020 for emerging economic bodies 
(ISSN : 2536 - 9555)

\section{Excerpt (17)}

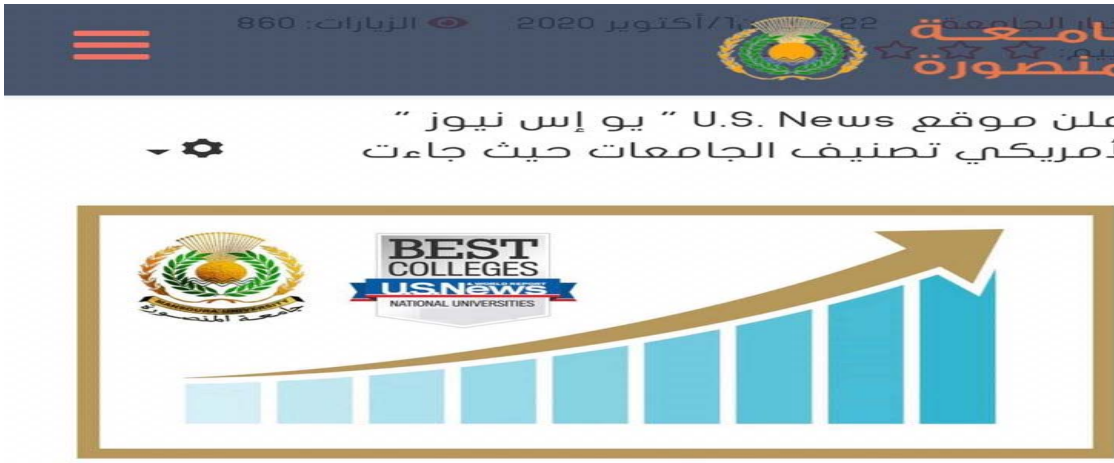

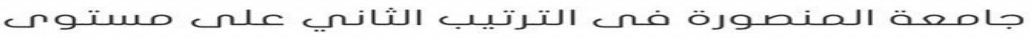

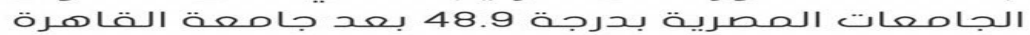

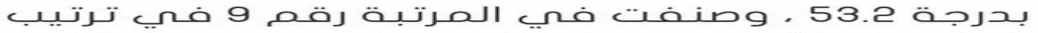

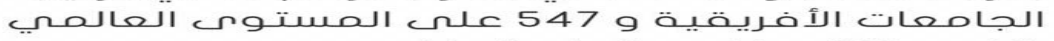

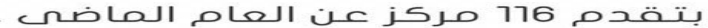

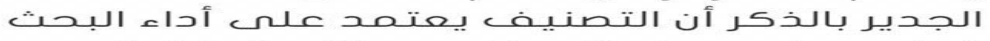

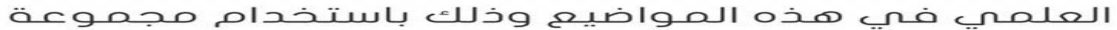

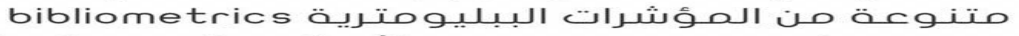

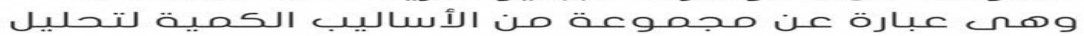

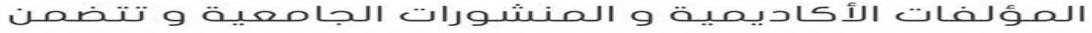

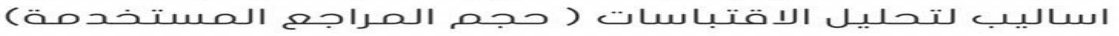

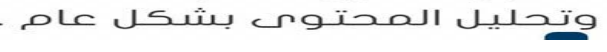

\section{Wansoura University}

6 October 2020

\section{Mansoura University University news} 860 visits

\section{U.S. New website announced the university ranking as follows:}

Mansoura University came second among Egyptian universities scoring 48.9 after Cairo University with 53.2. It came number 9 among the African Universities and 547 internationally with 116 in higher position than the previous year. Interesting to note that the rating depends on the performance of scientific research by applying a group of bibliometrics, which is a set of quantitative methods to analyze the academic literature and university publications, including methods for detecting plagiarism (value of reference used and content analysis in general). 


\title{
Discourse and Identity in the Digital World: Mansoura University Website as a Model
}

Dr. Rehab Farouk Gad

\author{
مجلة وادي النيل للاراسات والبحوث الإنسانية والاجتماعية والتربوية (مجلة علمية محكمة)
}

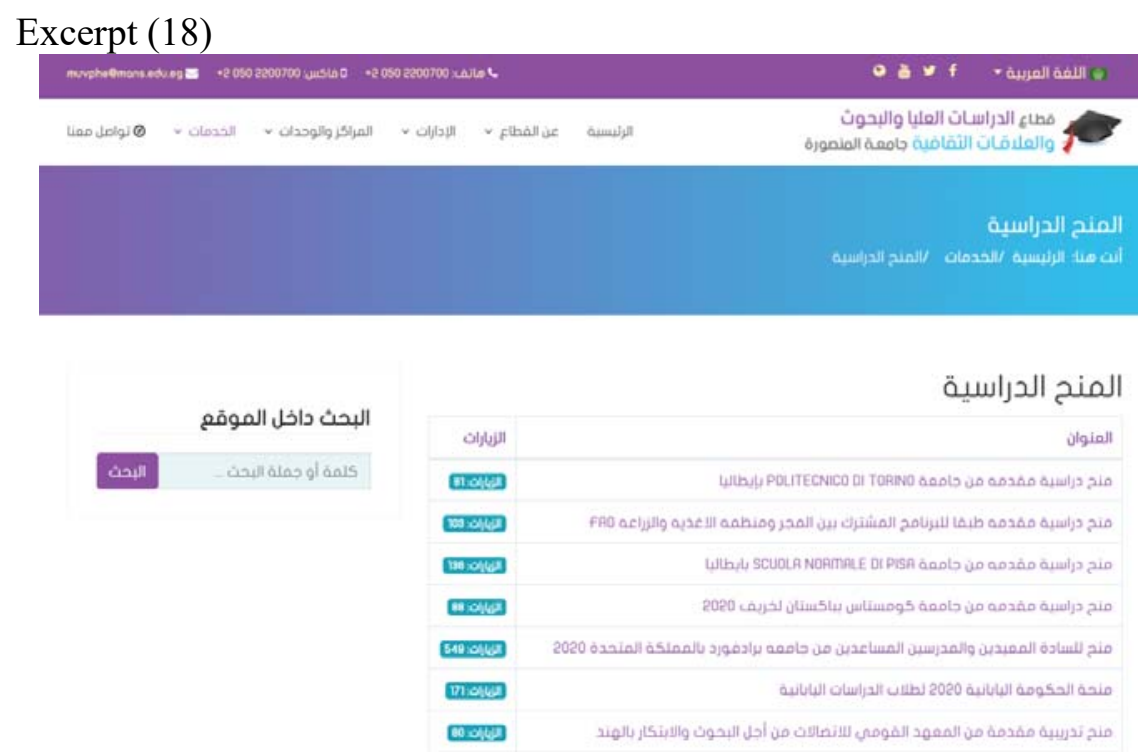

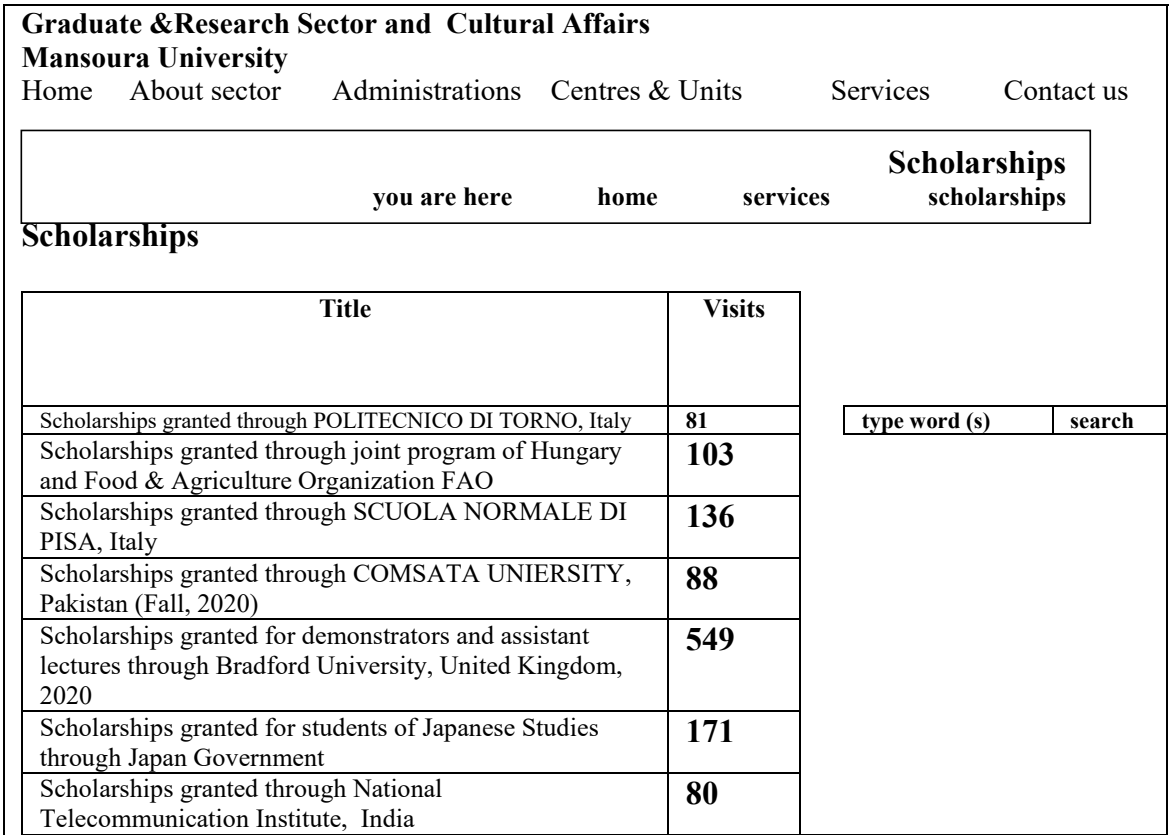


(ISSN : 2536 - 9555)

Excerpt (19)
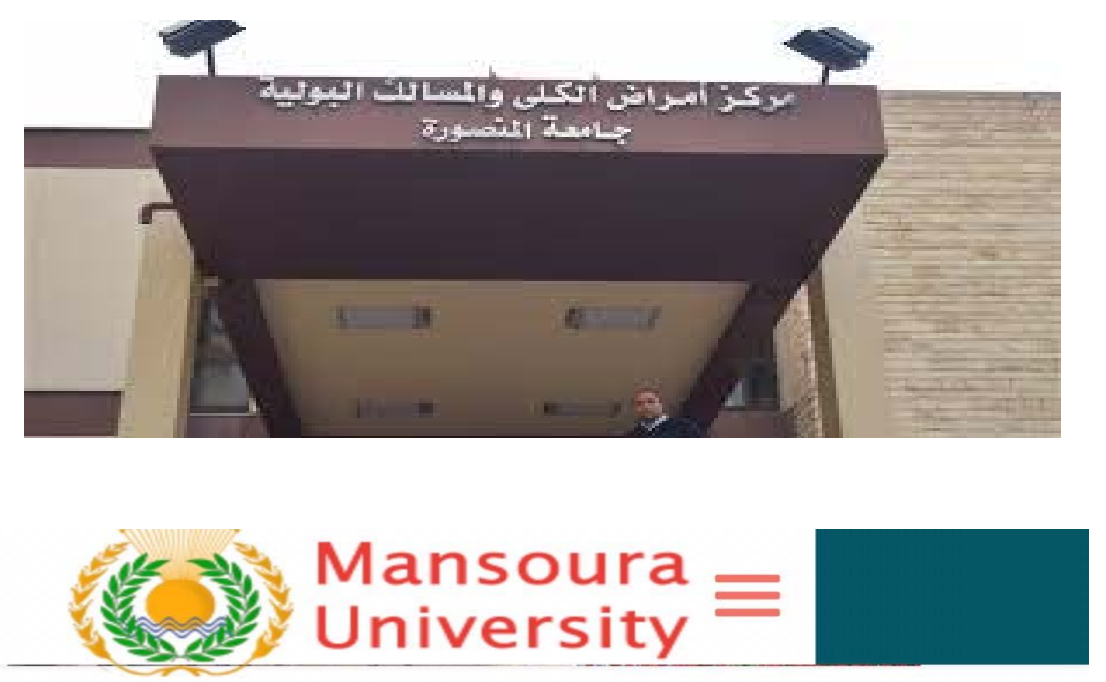

In May 1983, the Urology \& Nephrology Center was officially inaugurated. Since then, the activities of the center have been growing, both clinical and academic. The establishment of the center was an examplary work of Dr. M. A Ghoneim and two of his fellow urologists: Dr. A. Ashamallah and Dr. S. Hammady. Endourology; the use of endoscopy in urologic surgery; was starting in 70's. Yet it was finally settled in mid 80's. The center includes operations on Radical cystectomy and urinary diversion. New subspecialties were emerging: Pediatric urology, starting in late 80's and grew up to the limit of having its own ward in the new extension. Laparoscopy is a new endourologic field that has been established. Also, Urodynamics and voiding dysfunction has also evolved, with over 3000 patients examined in the urodynamic lab of the center and incontinence surgery developed.

Website: www.unc.edu.eg 
Discourse and Identity in the Digital World: Mansoura University Website as a Model

Dr. Rehab Farouk Gad

مجلة وادي النيل للاراسات والبحوث الإنسانية والاجتماعية والتربوية (مجلة علمية محكمة)

Appendix (B)

Sample of informal language excerpts in MU website

Excerpt (20)

$$
\begin{aligned}
& \text { لو عندك حساب على تليجرام } \\
& \text { اشترك في القناة الرسمية لجامعة المنصورة على التئي التليجرام }
\end{aligned}
$$

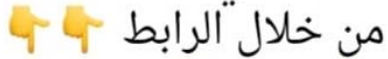

$$
\begin{aligned}
& \text { https://t.me/Mansoura_University }
\end{aligned}
$$

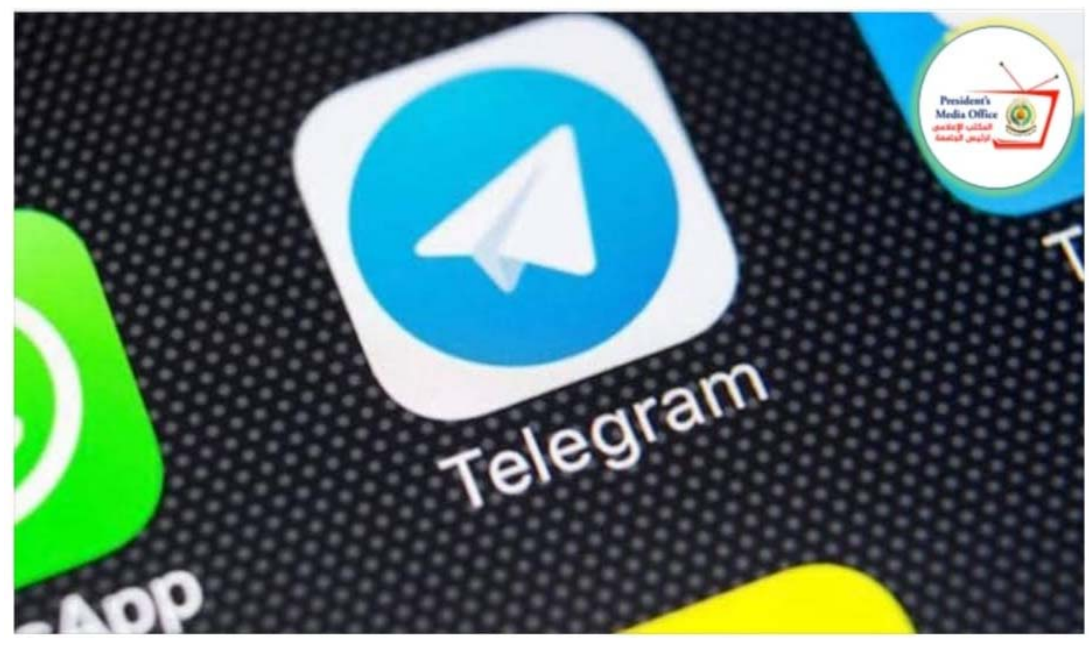

If you have a telegram account, subscribe to the official channel of Mansoura University via the link below

http://t.me/Mansoura University 
Excerpt (21)

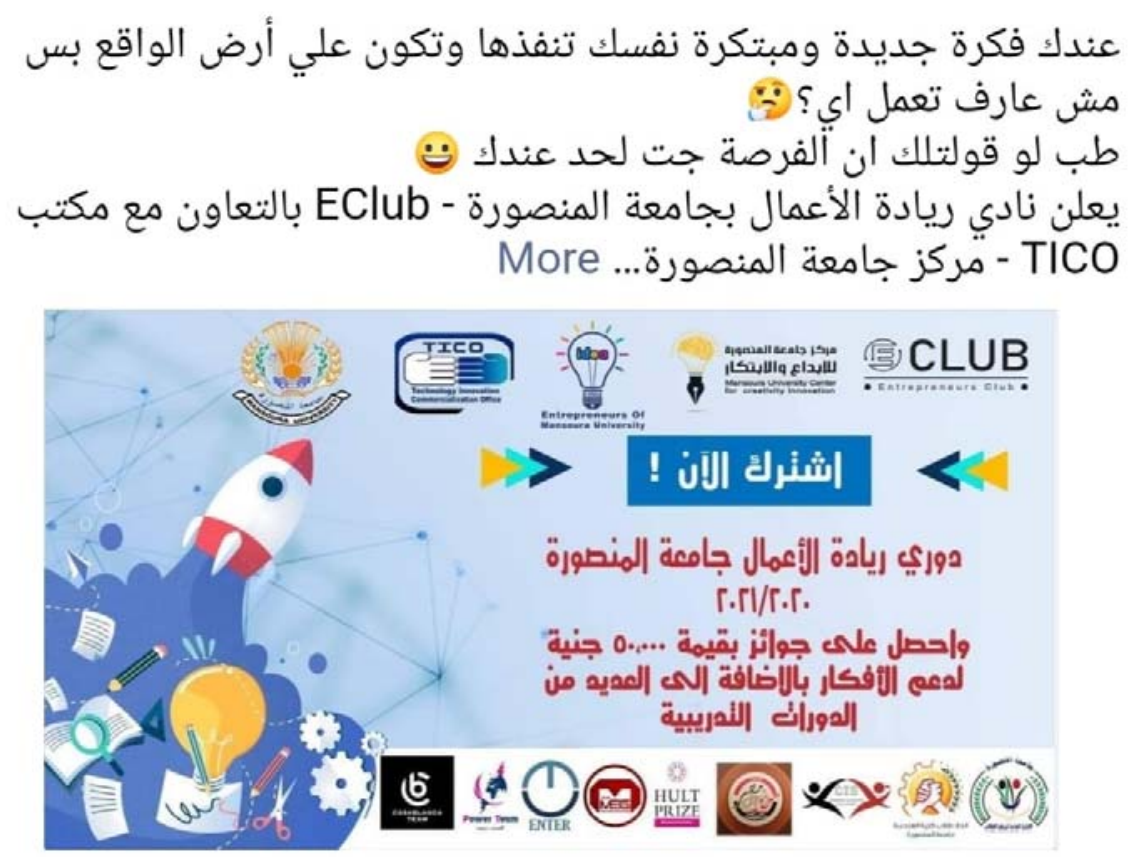

You have a new and innovative idea that you wish to turn it into reality, but you don't know what to do?

If I told you the chance is at hand!

The Entrepreneurs Club at Mansoura University EClub in cooperation with the TICO office- center of Mansoura Universityannounces.................More

\section{Register now}

Entrepreneurs club league 2020/2021

And win valuable prizes of 50,000 EGP to support ideas, plus a package of training courses 
Discourse and Identity in the Digital World: Mansoura University Website as a Model

Dr. Rehab Farouk Gad

مجلة وادي النيل للار اسات والبحوث الإنسانية والاجتماعية والتربوية (مجلة علمية محكمة)

Excerpt (22)

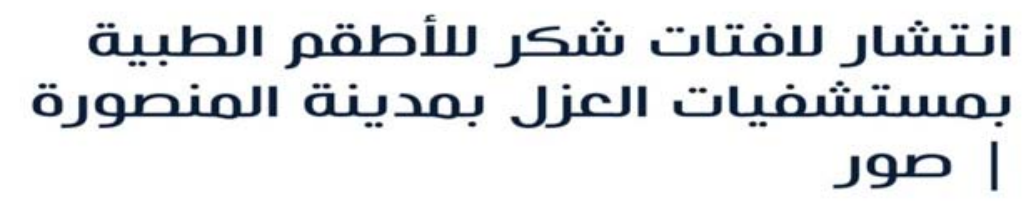

$02: 43$ | 2020-7-21

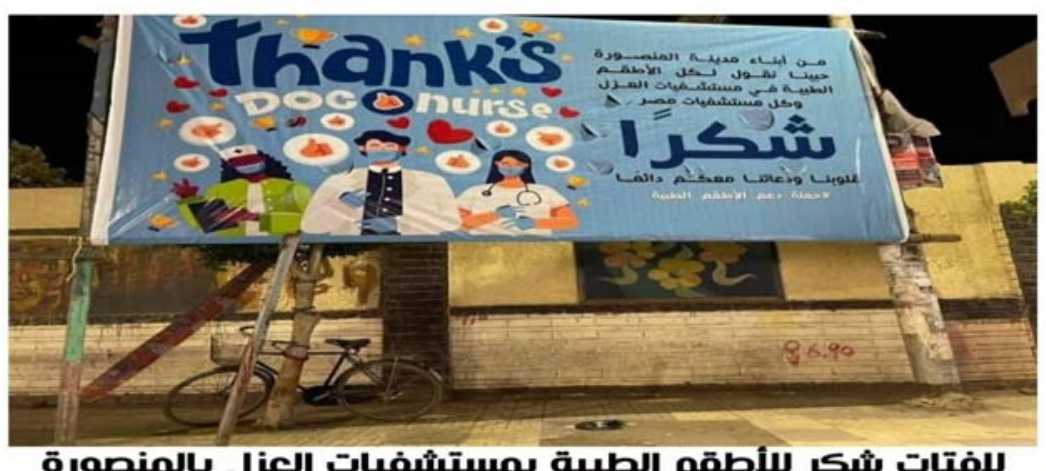

لافتات ثكر للأطقم الطبية بمستشفيات العزل بالمنصورة

Thank you banners for medical staff of isolation hospitals spread in Mansoura city

As residents of Mansoura city, we came here would to say to all medical staff of isolation hospitals in Mansoura, and all hospitals in Egypt Thank YOU

Our hearts and prayers are always with you

$$
\text { \# Medical staff support campaign }
$$

Thank you banners for medical staff of isolation hospitals in Mansoura 
(ISSN : 2536 - 9555)

Excerpt (23)
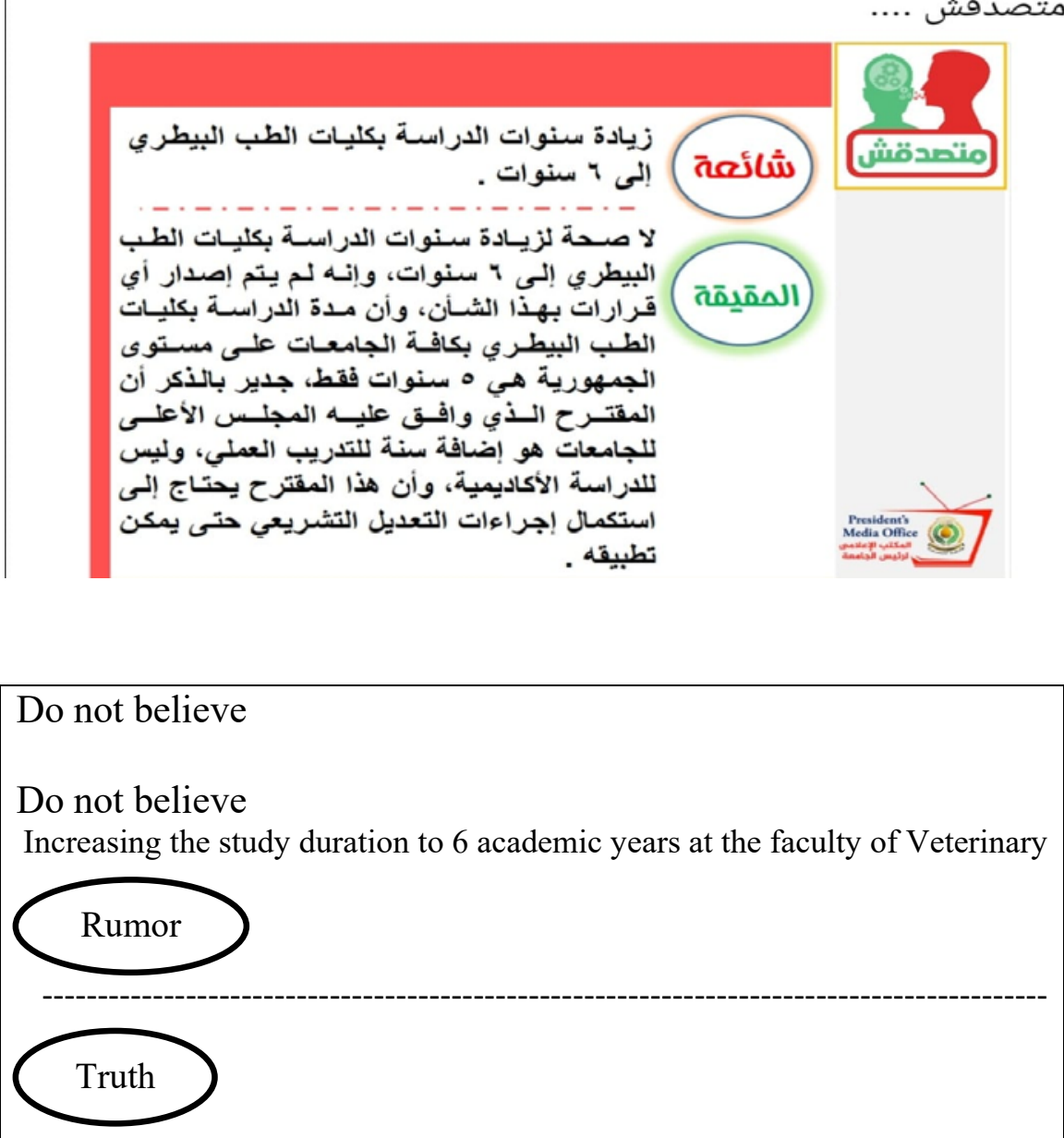

It is not true that the number of academic years at the faculty of Veterinary has been increased to 6 years as no decisions has been made on that matter. The number of academic years at the faculties of Veterinary is five years only in all Egyptian Universities. It is worth mentioning that the proposal approved by the Higher Council of Universities is to add one year of practical training, not for an academic study. This proposal necessitates the completion of the legislative procedures to be applied. 